University of Nebraska - Lincoln

DigitalCommons@University of Nebraska - Lincoln

Characterization of gas chemistry and noble-gas isotope ratios of inclusion fluids in magmatic-hydrothermal and magmatic-steam alunite

Robert O. Rye

U.S. Geological Survey, rrye@usgs.gov

G.P. Landis

U.S. Geological Survey

Follow this and additional works at: https://digitalcommons.unl.edu/usgsrye

Part of the Geochemistry Commons

Rye, Robert O. and Landis, G.P., "Characterization of gas chemistry and noble-gas isotope ratios of inclusion fluids in magmatic-hydrothermal and magmatic-steam alunite" (2005). Geochemistry of Sulfate Minerals: A Tribute to Robert O. Rye. 5.

https://digitalcommons.unl.edu/usgsrye/5

This Article is brought to you for free and open access by the US Geological Survey at DigitalCommons@University of Nebraska - Lincoln. It has been accepted for inclusion in Geochemistry of Sulfate Minerals: A Tribute to Robert O. Rye by an authorized administrator of DigitalCommons@University of Nebraska - Lincoln. 


\title{
Characterization of gas chemistry and noble-gas isotope ratios of inclusion fluids in magmatic-hydrothermal and magmatic-steam alunite
}

\author{
G.P. Landis*, R.O. Rye \\ U.S. Geological Survey, MS 963, P.O. Box 25046, Denver Federal Center, Denver, Colorado 80225, U.S.A.
}

Accepted 1 June 2004

\begin{abstract}
Chemical and isotope data were obtained for the active gas and noble gas of inclusion fluids in coarse-grained samples of magmatic-hydrothermal and magmatic-steam alunite from well-studied deposits (Marysvale, Utah; Tambo, Chile; Tapajós, Brazil; Cactus, California; Pierina, Peru), most of which are discussed in this Volume. Primary fluid inclusions in the alunite typically are less than $0.2 \mu \mathrm{m}$ but range up to several micrometers. Analyses of the active-gas composition of these alunitehosted inclusion fluids released in vacuo by both crushing and heating indicate consistent differences in the compositions of magmatic-hydrothermal and magmatic-steam fluids. The compositions of fluids released by crushing were influenced by contributions from significant populations of secondary inclusions that trapped largely postdepositional hydrothermal fluids. Thermally released fluids gave the best representation of the fluids that formed primary alunite. The data are consistent with current models for the evolution of magmatic-hydrothermal and magmatic-steam fluids. Magmatic-steam fluids are vapordominant, average about $49 \mathrm{~mol} \% \mathrm{H}_{2} \mathrm{O}$, and contain $\mathrm{N}_{2}, \mathrm{H}_{2}, \mathrm{CH}_{4}, \mathrm{CO}, \mathrm{Ar}, \mathrm{He}, \mathrm{HF}$, and $\mathrm{HCl}$, with $\mathrm{SO}_{2}$ the dominant sulfur gas (average $\mathrm{SO}_{2} / \mathrm{H}_{2} \mathrm{~S}=202$ ). In contrast, magmatic-hydrothermal fluids are liquid-dominant, average about $88 \mathrm{~mol} \% \mathrm{H}_{2} \mathrm{O}$, and contain $\mathrm{N}_{2}, \mathrm{H}_{2}, \mathrm{CO}_{2}$, and $\mathrm{HF}$, with $\mathrm{H}_{2} \mathrm{~S}$ about as abundant as $\mathrm{SO}_{2}$ (average $\mathrm{SO}_{2} / \mathrm{H}_{2} \mathrm{~S}=0.7$ ). The low $\mathrm{SO}_{2} / \mathrm{H}_{2} \mathrm{~S}$ and $\mathrm{N}_{2} / \mathrm{Ar}$ ratios, and the near-absence of $\mathrm{He}$ in magmatic-hydrothermal fluids, are consistent with their derivation from degassed condensed magmatic fluids whose evolution from reduced-to-oxidized aqueous sulfur species was governed first by rock and then by fluid buffers. The high $\mathrm{SO}_{2} / \mathrm{H}_{2} \mathrm{~S}$ and $\mathrm{N}_{2} / \mathrm{Ar}$ with significant concentrations of $\mathrm{He}$ in magmatic-steam fluids are consistent with derivation directly from a magma. None of the data supports the entrainment of atmospheric gases or mixing of air-saturated gases in meteoric water in either magmatic-hydrothermal or magmatic-steam fluids. Thus, the oxidation of $\mathrm{SO}_{2}$ to aqueous sulfate in the magmatic-steam fluids did not result from mixing with atmospheric oxygen. Both of the fluid types are characterized by high $\mathrm{H}_{2}$ contents that range from $0.2 \mathrm{~mol} \%$ to the extraordinarily large amounts $(66 \mathrm{~mol} \%)$ observed in some magmatic-steam fluids. Modeling of gas speciation using SOLVGAS requires most of the gas species to have been in disequilibrium at the time of their trapping in the fluid inclusions. The origin of such extreme $\mathrm{H}_{2}$ concentrations, although problematic, is thought to be largely related to accumulation of $\mathrm{H}_{2}$ from the reaction of water with ferrous iron during the rise of
\end{abstract}

* Corresponding author. Tel.: +1 303236 5406; fax: +1 3032366030 .

E-mail address: g_landis@usgs.gov (G.P. Landis). 
magma and probably even after exsolution of fluid from a magma. The large contents of reduced gases in the inclusion fluids are far in excess of those observed in volcanic emanations, and are thought to reflect the close "sampling position" of the host alunite relative to the location of the magma. Isotope ratios of $\mathrm{He}$ and $\mathrm{Ne}$ indicate largely crustal sources for these gases in the alunite parental fluids derived from Tertiary magmas, but a greater mantle component for the gases in alunite parental fluids derived from Proterozoic magmas.

Published by Elsevier B.V.

Keywords: Magmatic gas; Fluid inclusions; Gas chemistry; Hydrogen; Helium; Neon; Argon; Noble-gas isotopes; Alunite; Hydrothermal fluids

\section{Introduction}

Alunite has proved to be a remarkably useful mineral in the study of magmatic, hydrothermal, and supergene processes, preserving isotopic and other geochemical evidence that characterizes the processes and environments of formation. The mineralogy, crystallography, thermodynamics, and geochronology of alunite-group minerals have been reviewed by Stoffregen et al. (2000). Stable-isotope characteristics and environments of formation of alunite have been reviewed by Rye et al. (1992), and the trace-element chemistry is reviewed by Deyell et al. (this Volume). The nature of fluid-inclusion and other gas sites, and the gas diffusion parameters and retention of primary gases in alunite fluid inclusions are described by Landis et al. (this Volume).

Hydrothermal alunite occurs in three acid-sulfate environments: magmatic-hydrothermal, magmaticsteam, and steam-heated. Models showing the environment of deposition of these types of alunite and their relationship to the evolution of magmatic fluid are reviewed in several papers in this Volume. The quantitative aspects of phase relationships of magmatic fluids in the various environments have been reviewed by Fournier (1987, 1999), Giggenbach (1997), and Muntean and Einaudi (2001). Steamheated alunite is typically very fine grained, and suitably coarse samples were not available for the analyses reported here. Thus, only two of the hydrothermal environments of alunite formation are considered in this report.

In the magmatic-hydrothermal environment, alunite is typically formed by the alteration of feldspar by $\mathrm{H}_{2} \mathrm{SO}_{4}$ derived from the disproportionation of magmatic $\mathrm{SO}_{2}$ in a condensing magmatic vapor plume that separated from a counterpart brine at the brittleductile transition at about $400{ }^{\circ} \mathrm{C}$ (cf. Smith and
Bruhn, 1984). The redox buffering of this vapor plume by its surrounding rocks near the brittle-ductile transition produces a fluid that is initially $\mathrm{H}_{2} \mathrm{~S}$ dominant. Both vapor and the residual saline fluids may be the source of later high-sulfidation ore deposition. This type of alunite most commonly replaces feldspars in igneous rocks and occurs in an assemblage of quartz+alunite+kaolinite+pyrite, with consecutive zones of alteration from vuggy-silica cores to peripheral propylitic+pyrite alteration. The $\delta^{34} \mathrm{~S}$ values of magmatic-hydrothermal alunite are large, and alunite-pyrite sulfur-isotope fractionations display equilibrium values that reflect the temperature of deposition.

The magmatic-steam environment is characterized by veins of coarse-banded alunite thought to have precipitated from a rapidly rising and expanding magmatic vapor plume inferred to be $\mathrm{SO}_{2}$-dominant. The $\delta^{34} \mathrm{~S}$ values of the alunite are low (similar to the value for bulk sulfur in the magmatic vapor system) and clearly do not reflect equilibrium between reduced and oxidized sulfur species in the parental fluids. Presumably, the parental vapor rises so fast that the sulfur isotopic composition of the alunite reflects only that of the bulk sulfur in the system and not the values expected from the equilibration of reduced and oxidized aqueous sulfur species. It is currently unclear how the sulfate for magmatic-steam alunite is produced. The coarse-banded crystals may exhibit a sawtooth-shaped distribution of trace elements, and may have minor associated primary hematite, but have relatively little associated pyrite and rock alteration.

This reconnaissance study presents the first quantitative chemical data on reactive- and noblegas isotope species contained in inclusion fluids in alunite from several well-documented localities. Fluid inclusions in magmatic-hydrothermal and magmatic-steam alunite were examined optically, 
and data are presented on the gas compositions of inclusion fluids that were released by crushing and by subsequent heating in vacuo. There are similarities and differences of gas compositions between magmatic-hydrothermal and magmatic-steam alunite inclusion fluids, as well as among the fluids in each type of alunite from different localities. Neither type of alunite has fluid that contains atmospheric gases. The gas compositions are examined for approach to equilibrium among species using the computer program SOLVGAS (Symonds and Reed, 1993). Surprisingly, both the magmatic-steam and the magmatic-hydrothermal alunite show that the entrapped gases in the fluids were out of equilibrium largely because of the presence of $\mathrm{H}_{2}$ in amounts that far exceed those observed in volcanic gases. This $\mathrm{H}_{2}$ likely originates largely from the reaction of water with ferrous iron in the magma and is trapped in the alunite fluid inclusions because of the close proximity to the magmatic source of the fluids. In spite of these enigmatic high $\mathrm{H}_{2}$ contents, the results for magmatic-steam and magmatic-hydrothermal fluids from different localities are internally consistent and support existing models. Although this is a reconnaissance investigation and some of the discussion that it engenders is speculative, the consistency of the results suggests that further detailed studies on the reactive- and noble-gas isotope composition of alunite inclusion fluids are merited.

Magmatic-steam and magmatic-hydrothermal alunite precipitate from aqueous fluids that can comprise both liquid and vapor. Both may contain gas or volatile components such as $\mathrm{He}, \mathrm{HCl}, \mathrm{HF}$, $\mathrm{SO}_{2}, \mathrm{H}_{2} \mathrm{~S}$, and $\mathrm{H}_{2} \mathrm{O}$ that are released in a vacuum system for analytical measurements. In this paper, "gas" or "volatiles" refer to species in the fluids rather than to the phase of the fluid, which can be supercritical or consist of one or two subcritical phases (liquid and vapor). Magmatic steam is an imprecise term that originates from the first description of magmatic-steam alunite (Rye et al., 1992) and implies a fluid that rose rapidly from a magma to shallow levels. Regardless of the phase relations in the fluid, magmatic steam refers here to a lowdensity fluid containing a variable component of water and may be 'wet' or 'dry', depending on the degree of condensation of water vapor (Fournier, 1999).

\section{Sample description}

We have focused our study on well-documented samples of magmatic-hydrothermal and magmaticsteam alunite that are available from previously published investigations. The samples of magmaticsteam alunite are from Marysvale, Utah (Cunningham et al., 1984; Rye et al., 1992), Cactus, California (Rye et al., 1992), Tambo, Chile (Deyell et al., this Volume), and Pierina, Peru (Fifarek and Rye, this Volume). The samples of magmatic-hydrothermal alunite are from Tapajós, Brazil (Juliani et al., this Volume), Tambo (Deyell et al., this Volume), and Pierina (Fifarek and Rye, this Volume). The two genetic types are distinguished by their geological occurrence, and by stable-isotope data that indicate a lack of sulfur isotopic exchange among aqueous sulfur species in their parental fluids for magmatic-steam alunite (Rye et al., 1992). Based on these criteria, the Marysvale alunite is clearly the archetype for the magmatic-steam environment. Where rates of fluid ascent were slower or distances from source magmas were greater, or where fluid-wallrock interaction was significant, various degrees of sulfur-isotope exchange between the aqueous sulfur species in the parental fluids may have occurred. These modifying effects on magmatic-steam fluids are best studied in the alunite at other areas, such as Tambo and Pierina. The designation of magmatic-steam and magmatichydrothermal alunite implies a genetic model for the processes that produced the parent fluids. We recognize that a continuum or broad overlap of processes and environments that produce these alunite types is likely.

\subsection{Magmatic-steam alunite samples}

\subsubsection{Marysvale}

The best example of magmatic-steam alunite (Cunningham et al., 1984, 1996; Rye et al., 1992; Rowley et al., 1994; Rye, this Volume) occurs at Alunite Ridge in the Marysvale volcanic field in westcentral Utah above a 14 Ma intrusion. Coarse-grained alunite fills near-vertical fractures up to $20 \mathrm{~m}$ in width in intermediate-composition volcanic rocks overlying an unexposed, shallow intrusive body. The veins consist of multiple layers, each about $1-3 \mathrm{~cm}$ wide, of plumose alunite with minor hematite. Microprobe 
studies have shown the presence of sawtooth patterns of $\mathrm{P}, \mathrm{Sr}$, and $\mathrm{Ba}$ across growth bands that are interpreted to represent burst and decay phenomena in the parent fluids (Cunningham et al., 1996; Rye, this Volume). The alunite is thought to have formed at a depth of $<300 \mathrm{~m}$ from the paleosurface (Cunningham, personal communication) from fluids derived from direct degassing of a shallow $(\leq 1 \mathrm{~km})$ epizonal magma; each alunite layer and sawtooth trace-element band represents a single degassing event or pulse of magmatic vapor. The $\delta^{34} \mathrm{~S}$ values of alunite are almost constant $(\sim 1 \%)$ and are the same as that of the bulk magmatic sulfur and sparse sulfides in the wallrocks (Rye et al., 1992). Observations of fluid inclusions indicate crystallization from a low-density fluid (Cunningham et al., 1984).

\subsubsection{Cactus}

Magmatic-steam acid-sulfate alteration overlies gold and base-metal vein mineralization, of the 'adularia'-'sericite' type, in the Middle Buttes Miocene quartz latite to rhyolite volcanic complex of the western Mojave Desert, California (Smith, 1941; Troxel and Morton, 1962). Alunite-producing alteration was roughly coeval with volcanism, and an Ar age of 18.4 Ma was obtained from fine-grained alunite (Bottaro, 1987). The magmatic-steam alunite occurs as coarse veins and volcanic breccia filling that cut steam-heated alteration without significant associated kaolinitic wallrock alteration. This alunite also has uniformly low $\delta^{34} \mathrm{~S}$ values, contains vapor-rich fluid inclusions, and does not appear to be related to the main Cactus mineralization. Low-temperature (130$170{ }^{\circ} \mathrm{C}$ ) intramineral oxygen isotopic data for this alunite suggest deposition in a shallow environment in which atmospheric oxygen might have been involved in the oxidation of sulfur gases to produce aqueous sulfate. The alunite intramineral oxygen-isotope thermometer has inherent uncertainties (Rye et al., 1992; Rye, this Volume), but if the Cactus sample is indeed of shallow low-temperature origin, the Cactus sample is an excellent one to test for possible involvement of atmospheric oxygen in the oxidation of sulfur gas species to aqueous sulfate.

\subsubsection{Tambo}

Epithermal mineralization of the El Indio-Tambo deposits is hosted by intensely fractured rhyolitic to dacitic, lithic ash-flow tuffs and other volcaniclastic rocks of Upper Oligocene to Upper Miocene age which are part of the El Indio-Pascua belt, Chile (Jannas et al., 1999; Deyell et al., this Volume). The main eruptive and hypabyssal volcanic activity occurred from 27 to $14 \mathrm{Ma}$, with isolated episodes of activity between 12 and $11.7 \mathrm{Ma}$. In the northern portion of the mineral belt, minor intrusions of dacitic dikes and eruptions of ignimbrite occurred up to $2 \mathrm{Ma}$. The deposits exhibit multiple stages of alunite formation representing both magmatic-hydrothermal and magmatic-steam acid-sulfate environments. Coarsely banded magmatic-steam alunite (Banded Stage alunite) occurs in veins up to 20 -cm wide, and crosscuts both magmatic-hydrothermal alunite of pre-ore Stage 1 (11.0 Ma) and Stage 2 breccia alteration (8.7 Ma). Textural relations, geochronology, and stable-isotope data indicate that deposition of Stage 3 alunite (8.2 Ma) and magmatic-steam Banded Stage alunite overlaps in time. As will be discussed, the transitional nature of this alunite is supported by our gas data. The Tambo samples offer the opportunity to trace the evolution of fluids through different types and stages of alunite deposition. Stage 3 alunite is a transitional type between those of Stage 2 (magmatic-hydrothermal) and the Banded Stage alunite (magmatic-steam).

\subsubsection{Pierina}

The Pierina $\mathrm{Au}-\mathrm{Ag}$ deposit (Fifarek and Rye, this Volume) is in the Cordillera Negra, west of the Rio Santa and Cordillera Blanca batholith, within a largely volcanic section of calc-alkalic lavas, tuffs, and pyroclastic breccias, and minor epiclastic sedimentary rocks. The orebody occurs in rhyolite ash-flow tuffs overlying a footwall sequence of andesitic and dacitic flows. Penecontemporaneous with the rhyolite tuffs are breccias, tuffs, and flow domes in, and marginal to, a volcanic vent complex that is south of the orebody and represents small phreatic magmatic eruptions. Hydrothermal alunite in the orebody and sericitic alteration $4 \mathrm{~km}$ to the south near the domed vent seem to be contemporaneous and have been dated at about 14.5 Ma by K-Ar methods. Magmaticsteam alunite is rare. It occurs as moderately to coarsely plumose vein and breccia fillings (Stage 4) that postdate magmatic-hydrothermal alunite, but its temporal relationship to other stages of mineralization 
is unknown. The magmatic-steam sample from Pierina exhibits a large increase in $\delta^{34} \mathrm{~S}(\approx 8 \%$ ) from that of the bulk sulfur composition ( $1 \%$ ), implying rates of fluid flow sufficiently slow to permit significant sulfur-isotope exchange between reduced and oxidized aqueous sulfur species in the parent fluids (Fifarek and Rye, this Volume).

\subsection{Magmatic-hydrothermal alunite samples}

\subsubsection{Tambo}

The Stage 2 magmatic-hydrothermal alunite of Deyell et al. (this Volume) is closely associated with early gold mineralization, but postdates major mineralized hydrothermal breccias. This alunite occurs as fine-grained $(<50 \mu \mathrm{m})$ tabular crystals and as compositionally zoned overgrowths on bladed alunite that is up to $1 \mathrm{~cm}$ long on barite and breccia fragments.

\subsubsection{Pierina}

The magmatic-hydrothermal alunite of Pierina formed during Stage 1 acid-sulfate alteration that overlaps and grades out from the central silicic alteration, forming part of the assemblage alunitequartz \pm pyrophyllite, dickite, kaolinite. This alunite type occurs typically as pink, platy to tabular or bladed crystals up to $4 \mathrm{~mm}$ in length, commonly intergrown with pyrite. The rock alteration described by Fifarek and Rye (this Volume) indicates a progressive neutralization of highly acidic aqueous fluids that migrated outward from zones of more focused fluid flow. Fluid temperatures, based on alunite-pyrite sulfur isotopic data, were about $240{ }^{\circ} \mathrm{C}$.

\subsubsection{Tapajós}

Alunite, identified as magmatic-hydrothermal by Juliani et al. (this Volume), formed as part of an alteration assemblage related to high-sulfidation mineralization $(1.87 \mathrm{Ga})$ genetically linked to the magmatic activity on what was then the margin of the Amazonian craton. Postcaldera volcanic rocks host the high-sulfidation mineralization that occurs in explosive hydrothermal breccia bodies and massive, hematite-rich, vuggy-silica caps. Quartz-alunite alteration, formed under a silica caprock, extends up to $200 \mathrm{~m}$ from the breccia centers and is known to occur up to $230 \mathrm{~m}$ below the surface. Of the five stages of alunite recognized at shallow levels $\left(\mathrm{A}_{1}-\mathrm{A}_{5}\right)$, our sample belongs to $\mathrm{A}_{5}$, a late-stage rose-colored, finegrained, randomly oriented alunite that crosscut and replaced the branching crystals of Stage $\mathrm{A}_{4}$ (Juliani et al., this Volume). Sulfur isotopic data for alunite and coexisting pyrite indicate formation at 130 to $400{ }^{\circ} \mathrm{C}$, consistent with equilibrium between aqueous sulfide and sulfate in the parental fluids. The Tapajós occurrence was remarkably little affected by later regional metamorphic or supergene events, largely because of burial in a shallow graben shortly after the mineralization event.

\section{Fluid inclusions in magmatic-steam and magmatic-hydrothermal alunite}

Fluid-inclusion investigations, especially when combined with isotope data on host minerals, have long been one of the cornerstones of geochemical studies of ore-forming fluids in hydrothermal systems. Such studies have provided information on the temperature and salinity of fluids, as well as the chemistry and isotopic composition of components of both the ore-forming (primary and pseudosecondary inclusions) and the postdepositional (secondary inclusions) fluids (e.g., Roedder, 1984). Very little previous work exists on the fluid inclusions in alunite (cf. Cunningham et al., 1984). Fluid inclusions in alunite investigated in this study and in Landis et al. (this Volume) are generally $\leq 1 \mu \mathrm{m}$ in diameter, have high gas/liquid ratios, and are too small for detailed temperature-salinity-clathrate studies (Roedder, 1984). However, temperature data often can be obtained from mineral assemblages or calculations of sulfur-isotope equilibrium fractionation for coexisting alunite and pyrite, and from oxygen-isotope fractionations between sulfate and the OH site in alunite (Rye et al., 1992). Photomicrographs in Fig. 1 illustrate rare $1-2 \mu \mathrm{m}$ gas-rich inclusions in specimens of magmatic-steam alunite. Most inclusions in our samples are 0.2 to $0.01 \mu \mathrm{m}$ and are gas-rich. Fluid inclusions in magmatichydrothermal alunite are described by Landis et al. (this Volume).

Differences between fluid-inclusion populations in samples of magmatic-hydrothermal and magmaticsteam alunite were not observed. Both populations exhibited high gas/liquid ratios; and two-phase liquid- 

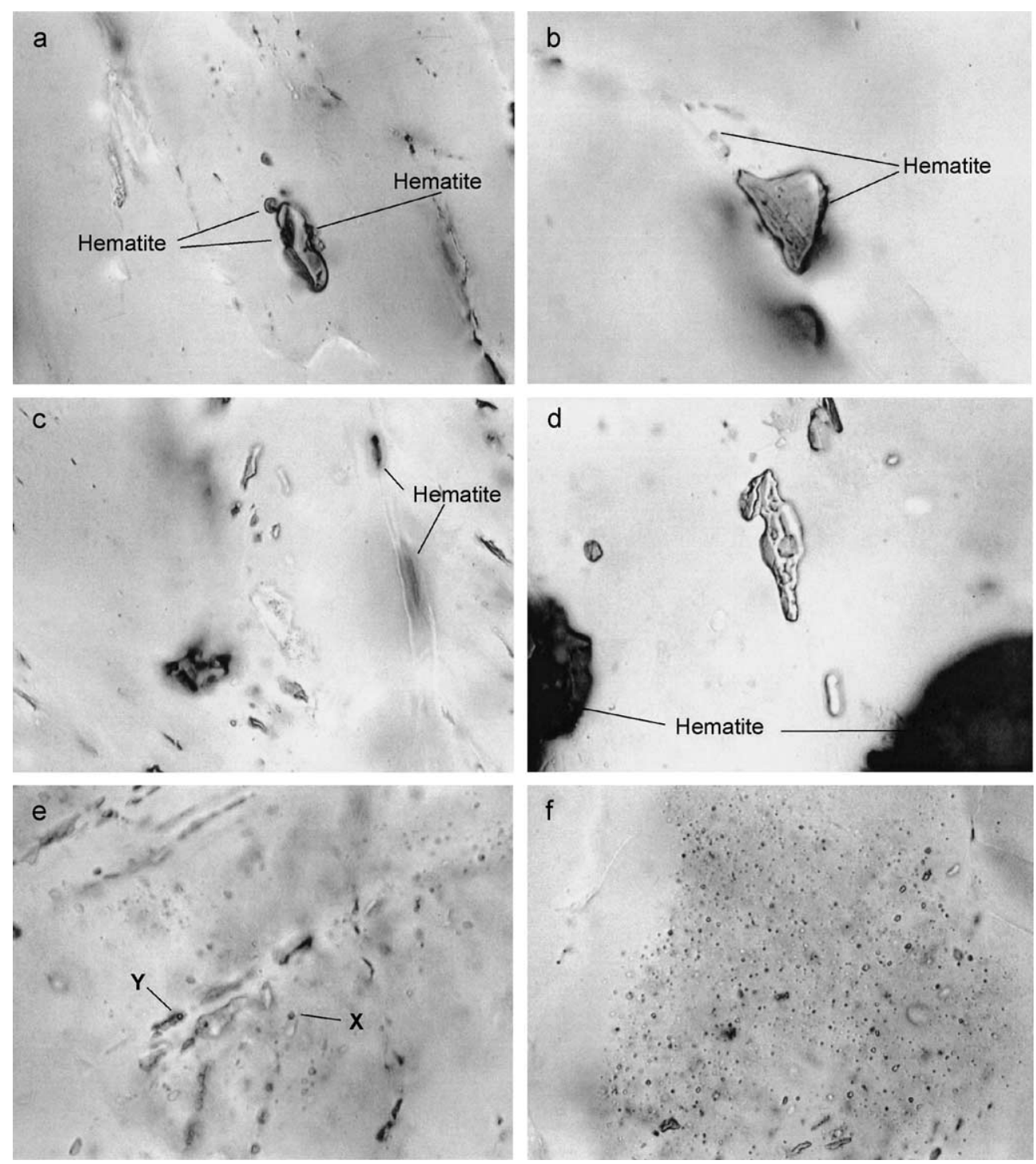

Fig. 1. Photomicrographs of fluid inclusions in magmatic-steam alunite. Width of the field of view of each image is $7.2 \mu \mathrm{m}$. (a) Cactus alunite with $0.9 \mu \mathrm{m}$ vapor-dominant inclusion nucleated around $0.2 \mu \mathrm{m}$ primary hematite grains. (b) Cactus alunite with unusually large $1.1 \mu \mathrm{m}$ vaporrich inclusion. (c) Marysvale alunite vapor inclusions with faint wispy outlines of crystal domains made evident by the change in long-axis orientation of elongate inclusions. (d) Tambo alunite with $2.25 \mu \mathrm{m}$ vapor inclusion near large primary hematite (dark) solid inclusions. (e) El Indio alunite with visible gas bubbles in a field otherwise predominantly of vapor-rich inclusions. Inclusion to left of $\mathrm{X}$ is $0.16 \mu \mathrm{m}$ wide with a $0.09-\mu \mathrm{m}$-diameter gas bubble, and the inclusion below $\mathrm{Y}$ is similar in size. (f) El Indio alunite crystal domain exhibiting a high concentration density of vapor inclusions of $0.06 \mu \mathrm{m}$ diameter. The El Indio alunite fluid-inclusion images are included because the deposit is similar to, and related to, the Tambo occurrence. See Landis et al. (this Volume) for magmatic-hydrothermal alunite fluid-inclusion images from the magmatichydrothermal deposits at Tapajós.

gas bubble inclusions only rarely were observed. The proportions of rare planes of large secondary fluid inclusions, along with 'dark' semiopaque regions, were similar in both types of alunite. Although no fluid inclusions were discernable in these regions, it is suspected that minor, but important, amounts of gas were released from these regions during crushing and thermal decrepitation of the samples. 
Table 1

Data for fluid-inclusion gas; results for active gas by QMS

\begin{tabular}{|c|c|c|c|c|c|c|c|c|c|c|c|c|c|c|c|c|c|}
\hline \multirow[t]{2}{*}{ Sample } & $\delta^{34} S_{\text {alunite }}$ & $\delta^{34} \mathrm{~S}_{\Sigma}$ & $\delta \mathrm{D}$ & Wt. & $\mathrm{N}_{2}$ & $\mathrm{O}_{2}$ & $\mathrm{Ar}$ & \multirow{2}{*}{$\frac{\mathrm{H}_{2}}{\%}$} & \multirow{2}{*}{$\frac{\mathrm{H}_{2} \mathrm{O}}{\%}$} & \multirow{2}{*}{$\frac{\mathrm{H}_{2} \mathrm{~S}}{\mathrm{ppm}}$} & \multirow{2}{*}{$\frac{\mathrm{SO}_{2}}{\mathrm{ppm}}$} & \multirow{2}{*}{$\frac{\mathrm{HCl}}{\mathrm{ppm}}$} & \multirow{2}{*}{$\frac{\mathrm{HF}}{\mathrm{ppm}}$} & \multicolumn{2}{|c|}{$\mathrm{CH}_{4} \mathrm{CO}_{2}$} & $\mathrm{CO}$ & \multirow{2}{*}{$\frac{\mathrm{He}}{\mathrm{ppm}}$} \\
\hline & Avg & Avg & Avg & $\mathrm{g}$ & $\%$ & ppm & ppm & & & & & & & $\%$ & $\%$ & $\%$ & \\
\hline \multicolumn{18}{|c|}{ Magmatic-steam alunite } \\
\hline $\begin{array}{l}\text { Thermally released } \\
\text { Marysvale }\end{array}$ & & & & Avg & 13.8 & 1459.0 & 7722.8 & 21.3 & 48.7 & 3.9 & 807.3 & 157.0 & 1226.8 & 0.7 & 3.1 & 13.3 & 303.7 \\
\hline M939a2 & 0.8 & 1.0 & -85 & 7.4 & 0.00 & 148 & 1358 & 1.05 & 2.43 & 0 & 138 & 6 & 0 & 1.80 & 0.56 & 693.98 & 251 \\
\hline M939a3 & & & & 5.4 & 52.44 & 7997 & 5460 & 18.29 & 18.43 & 0 & 4088 & 561 & 292 & 1.97 & 1.29 & 5.67 & 732 \\
\hline M939a4 & & & & 29.4 & 25.44 & 1890 & 2321 & 61.92 & 10.09 & 0 & 1686 & 435 & 558 & 0.95 & 0.79 & 0.00 & 1232 \\
\hline M341a & 1.2 & 1.0 & -82 & 15.7 & 17.37 & 1507 & 2181 & 23.25 & 53.29 & 0 & 1153 & 160 & 3527 & 0.83 & 0.94 & 3.50 & 330 \\
\hline M341b & & & & 14.0 & 2.44 & 164 & 1800 & 6.86 & 80.63 & 8 & 76 & 142 & 1075 & 0.27 & 8.18 & 1.28 & 81 \\
\hline \multicolumn{18}{|l|}{ Cactus } \\
\hline $\begin{array}{l}\text { Cactus } 2 \\
\text { Tambo Stage } 3\end{array}$ & -1.0 & 0.0 & -59 & 8.6 & 3.62 & 175 & 270 & 8.49 & 83.49 & 11 & 43 & 16 & 1282 & 0.08 & 3.04 & 1.10 & 24 \\
\hline \multicolumn{18}{|c|}{ Tambo- banded alunite } \\
\hline $\begin{array}{l}\text { T08a } \\
\text { Pierina }\end{array}$ & 1.1 & 2.0 & -48 & 7.4 & 20.21 & 1045 & 54,992 & 45.38 & 29.92 & 1 & 48 & 3 & 673 & 0.50 & 3.26 & & 44 \\
\hline P452 & 8.5 & 5.0 & -85 & 9.5 & 1.98 & 146 & 469 & 19.81 & 68.54 & 3 & 4 & 48 & 1400 & 0.17 & 9.30 & 0.00 & 40 \\
\hline $\begin{array}{l}\text { Crush-Released } \\
\text { Marysvale }\end{array}$ & & & & Avg & 21.2 & 1186.8 & 4734.0 & 18.0 & 46.3 & 13.3 & 450.5 & 107.8 & 685.9 & 0.7 & 1.1 & 18.2 & 232.3 \\
\hline M939a1 & & & & 4.3 & 0.00 & 3189 & 1835 & 1.73 & 15.62 & 0 & 3114 & 83 & 901 & 4.37 & 2.62 & 74.74 & 97 \\
\hline M341 & & & & 14.0 & 36.58 & 545 & 7385 & 35.81 & 10.74 & 0 & 0 & 11 & 65 & 0.02 & 0.75 & 15.30 & 6 \\
\hline M341 & & & & 14.0 & 33.72 & 116 & 8201 & 12.26 & 38.54 & 0 & 0 & 53 & 623 & 0.12 & 1.64 & 12.77 & 457 \\
\hline M341 & & & & 14.0 & 20.51 & 77 & 5360 & 15.32 & 53.74 & 0 & 0 & 45 & 1124 & 0.20 & 1.83 & 7.68 & 649 \\
\hline \multicolumn{18}{|l|}{ Cactus } \\
\hline Cactus A & & & & 5.3 & 36.85 & 2134 & 4607 & 48.67 & 10.35 & 0 & 1956 & 606 & 399 & 1.78 & 1.27 & 0.00 & 1110 \\
\hline Cactus 1 & & & & 15.4 & 21.25 & 4464 & 2667 & 16.29 & 55.70 & 0 & & 153 & 2971 & 0.88 & 0.63 & 3.93 & 293 \\
\hline \multicolumn{18}{|l|}{ Tambo Stage 3} \\
\hline T02b & & & & 6.6 & 19.54 & 19 & 4431 & 65.65 & 4.04 & 12 & 24 & 9 & 90 & 0.43 & 2.17 & 7.71 & 0 \\
\hline \multicolumn{18}{|l|}{ Tambo-banded alunite } \\
\hline T08a & & & & 7.4 & 48.62 & 127 & 14,228 & 13.59 & 21.72 & 22 & 43 & 10 & 0 & 0.14 & 1.14 & 20.13 & 0 \\
\hline KB-02a Early & 0.4 & 2.0 & -60 & & 0.59 & & 298 & 0.17 & 98.80 & 22 & 52 & & & 0.07 & 0.27 & & 70 \\
\hline KB-02a Late & & & & & 0.91 & & 534 & 0.41 & 98.00 & 26 & 81 & & & 0.14 & 0.37 & & 125 \\
\hline KB-02b Early & & & & & 1.40 & & 785 & 0.42 & 97.30 & 14 & 79 & & & 0.18 & 0.39 & & 120 \\
\hline KB-02b Late & & & & & 2.40 & & 715 & 0.41 & 96.70 & 77 & 56 & & & 0.14 & 0.31 & & 92 \\
\hline Pierina & & & & & & & & & & & & & & & & & \\
\hline P452 & & & & 9.5 & 53.24 & 11 & 10,496 & 23.18 & 0.26 & 0 & 0 & 0 & 0 & 0.16 & 0.67 & 21.44 & 0 \\
\hline Magmatic-hydroth & $l$ alunite & & & & & & & & & & & & & & & & \\
\hline $\begin{array}{l}\text { Thermally Released } \\
\text { Tambo Stage } 2\end{array}$ & & & & Avg & 0.6 & 80.5 & 275.9 & 8.8 & 87.9 & 15.3 & 11.1 & 17.6 & 2292.6 & 0.1 & 2.3 & 0.0 & 0.0 \\
\hline $\begin{array}{l}\text { T01a } \\
\text { Pierina }\end{array}$ & 27.3 & 2.0 & -28 & 8.0 & 0.20 & 44 & 200 & 1.44 & 97.55 & 17 & 3 & 8 & 2672 & 0.01 & 0.46 & 0.05 & 0 \\
\hline $\begin{array}{l}\text { P241 } \\
\text { Tapajos }\end{array}$ & 21.1 & 5.0 & -93 & 10.7 & 0.99 & 117 & 351 & 16.25 & 78.21 & 14 & 19 & 27 & 1913 & 0.09 & 4.21 & 0.00 & 0 \\
\hline $16 / 18\left(200{ }^{\circ} \mathrm{C}-1\right)$ & 26.7 & 5.0 & -43 & 7.0 & 10.62 & 221 & 314,905 & 7.26 & 10.41 & 187 & 110 & 136 & 76 & 1.25 & 38.87 & 0.00 & 216 \\
\hline $16 / 18\left(200{ }^{\circ} \mathrm{C}-2\right)$ & & & & 7.0 & 3.73 & 165 & 1321 & 10.44 & 58.43 & 292 & 94 & 117 & 0 & 3.89 & 22.77 & 0.51 & 212 \\
\hline $\begin{array}{l}\text { Crush-released } \\
\text { Tambo }\end{array}$ & & & & Avg & 13.5 & 63.5 & 3445.2 & 49.0 & 26.5 & 25.3 & 39.6 & 59.5 & 318.3 & 0.9 & 2.2 & 7.4 & 0.0 \\
\hline $\begin{array}{l}\text { T01a } \\
\text { Pierina }\end{array}$ & & & & 8.0 & 13.61 & 48 & 4070 & 65.09 & 11.30 & 20 & 38 & 47 & 313 & 0.21 & 1.64 & 7.69 & 0 \\
\hline P241 & & & & 10.7 & 13.31 & 79 & 2821 & 32.99 & 41.77 & 30 & 41 & 72 & 324 & 1.66 & 2.78 & 7.16 & 0 \\
\hline Tapajos & & & & & & & & & & & & & & & & & \\
\hline $16 / 18$ & & & & 7.0 & 29.04 & 8 & 3017 & 1.51 & 0.86 & 34 & 8 & 6 & 30 & 0.41 & 0.16 & 67.71 & 11 \\
\hline
\end{tabular}


Table 2

Data for fluid-inclusion gas; noble gas by MAP

\begin{tabular}{|c|c|c|c|c|c|c|c|c|c|c|c|c|c|}
\hline \multirow[t]{2}{*}{ Sample } & \multirow{2}{*}{$\frac{\text { Wt. }}{\mathrm{g}}$} & \multirow{2}{*}{$\frac{{ }^{4} \mathrm{He}}{\mathrm{mol} \mathrm{g}^{-1}}$} & \multirow{2}{*}{$\frac{{ }^{3} \mathrm{He}}{\mathrm{mol} \mathrm{g}^{-1}}$} & \multirow{2}{*}{$\frac{{ }^{20} \mathrm{Ne}}{\mathrm{mol} \mathrm{g}^{-1}}$} & \multirow{2}{*}{$\frac{{ }^{21} \mathrm{Ne}}{\mathrm{mol} \mathrm{g}^{-1}}$} & \multirow{2}{*}{$\frac{{ }^{22} \mathrm{Ne}}{\mathrm{mol} \mathrm{g}^{-1}}$} & \multirow[t]{2}{*}{${ }^{3} \mathrm{He} /{ }^{4} \mathrm{He}$} & \multirow[t]{2}{*}{$\mathrm{R} / \mathrm{Ra}$} & \multirow[t]{2}{*}{${ }^{20} \mathrm{Ne} /{ }^{22} \mathrm{Ne}$} & \multirow[t]{2}{*}{${ }^{21} \mathrm{Ne} /{ }^{22} \mathrm{Ne}$} & \multirow[t]{2}{*}{${ }^{4} \mathrm{He} /{ }^{21} \mathrm{Ne}$} & \multirow[t]{2}{*}{${ }^{4} \mathrm{He}^{40} \mathrm{Ar}^{\mathrm{a}}$} & \multirow{2}{*}{$\begin{array}{l}\text { Percent }(\%) \\
\text { magmatic } \mathrm{He}^{\mathrm{b}}\end{array}$} \\
\hline & & & & & & & & & & & & & \\
\hline \multicolumn{14}{|c|}{ Magmatic-steam alunite } \\
\hline Thermally released & & & & & & & & 0.15 & 8.98 & 0.08 & 818.46 & 0.039 & 1.58 \\
\hline \multicolumn{14}{|l|}{ Marysvale } \\
\hline M939a2 & & & & & & & & 0.064 & 7.904 & 0.113 & 1411.144 & 0.185 & 0.55 \\
\hline M939a3 & 5.4 & $4.85 \mathrm{E}-13$ & $1.08 \mathrm{E}-19$ & $2.15 \mathrm{E}-12$ & $7.41 \mathrm{E}-15$ & $2.37 \mathrm{E}-13$ & $2.22 \mathrm{E}-07$ & 0.160 & 9.067 & 0.031 & 65.545 & 0.134 & 1.76 \\
\hline M939a4 & 29.4 & $2.21 \mathrm{E}-13$ & $1.48 \mathrm{E}-20$ & $3.23 \mathrm{E}-14$ & $1.55 \mathrm{E}-16$ & $3.47 \mathrm{E}-15$ & $6.70 \mathrm{E}-08$ & 0.048 & 9.297 & 0.045 & 1426.165 & 0.531 & 0.36 \\
\hline M341a & 15.7 & $2.67 \mathrm{E}-13$ & $8.98 \mathrm{E}-21$ & $2.48 \mathrm{E}-14$ & 7.63E-17 & $2.60 \mathrm{E}-15$ & $3.36 \mathrm{E}-08$ & 0.024 & 9.554 & 0.029 & 3501.796 & 0.151 & 0.05 \\
\hline M341b & 14.0 & $5.73 \mathrm{E}-12$ & $1.70 \mathrm{E}-19$ & $9.39 \mathrm{E}-14$ & $8.80 \mathrm{E}-15$ & $2.54 \mathrm{E}-14$ & 2.97E-08 & 0.021 & 3.698 & 0.346 & 651.071 & 0.045 & 0.02 \\
\hline \multicolumn{14}{|l|}{ Cactus } \\
\hline Cactus 2 & 8.6 & $7.01 \mathrm{E}-13$ & $3.16 \mathrm{E}-20$ & $3.95 \mathrm{E}-11$ & $1.24 \mathrm{E}-13$ & $3.74 \mathrm{E}-12$ & $4.51 \mathrm{E}-08$ & 0.033 & 10.58 & 0.033 & 5.675 & 0.087 & 0.16 \\
\hline \multicolumn{14}{|l|}{ Tambo Stage 3} \\
\hline T02b & 6.6 & $1.15 \mathrm{E}-12$ & $1.86 \mathrm{E}-19$ & $7.41 \mathrm{E}-12$ & $2.04 \mathrm{E}-14$ & $6.62 \mathrm{E}-13$ & $1.62 \mathrm{E}-07$ & 0.117 & 11.188 & 0.031 & 56.314 & 0.000 & 1.21 \\
\hline \multicolumn{14}{|c|}{ Tambo-banded alunite } \\
\hline T08a & 7.4 & $1.17 \mathrm{E}-13$ & 4.33E-20 & $1.18 \mathrm{E}-12$ & $5.15 \mathrm{E}-15$ & $1.24 \mathrm{E}-13$ & $3.71 \mathrm{E}-07$ & 0.268 & 9.476 & 0.041 & 22.663 & 0.001 & 3.11 \\
\hline \multicolumn{14}{|l|}{ Pierina } \\
\hline P452 & 9.5 & $1.04 \mathrm{E}-12$ & 7.09E-19 & - & - & - & $6.83 \mathrm{E}-07$ & 0.494 & & & & 0.084 & 5.93 \\
\hline Crush-released & & & & & & & & 0.57 & 8.21 & 0.19 & 49.26 & 0.049 & 6.93 \\
\hline \multicolumn{14}{|l|}{ Marysvale } \\
\hline M341 & 14.0 & $6.02 \mathrm{E}-13$ & $9.82 \mathrm{E}-20$ & $1.05 \mathrm{E}-13$ & $9.24 \mathrm{E}-15$ & $2.99 \mathrm{E}-14$ & $1.63 \mathrm{E}-07$ & 0.118 & 3.512 & 0.309 & 65.077 & 0.056 & 1.23 \\
\hline \multicolumn{14}{|l|}{ Cactus } \\
\hline Cactus A & 5.3 & $2.67 \mathrm{E}-14$ & $2.24 \mathrm{E}-20$ & $1.97 \mathrm{E}-12$ & 7.23E-15 & $2.27 \mathrm{E}-13$ & $8.39 \mathrm{E}-07$ & 0.606 & 8.683 & 0.032 & 3.699 & 0.241 & 7.35 \\
\hline Cactus 1 & 15.4 & $1.34 \mathrm{E}-14$ & $2.31 \mathrm{E}-20$ & $4.50 \mathrm{E}-14$ & $7.78 \mathrm{E}-17$ & $4.70 \mathrm{E}-15$ & $1.73 \mathrm{E}-06$ & 1.249 & 9.591 & 0.017 & 171.916 & 0.110 & 15.40 \\
\hline \multicolumn{14}{|l|}{ Tambo Stage 3} \\
\hline $\mathrm{T} 02 \mathrm{~b}$ & 6.6 & $3.60 \mathrm{E}-14$ & $2.18 \mathrm{E}-20$ & $4.55 \mathrm{E}-11$ & $1.28 \mathrm{E}-13$ & $4.18 \mathrm{E}-12$ & $6.06 \mathrm{E}-07$ & 0.438 & 10.884 & 0.031 & 0.281 & 0.000 & 5.24 \\
\hline
\end{tabular}


Tambo-banded alunite

\begin{tabular}{|c|c|c|c|c|c|c|c|c|c|c|c|c|c|}
\hline T08a & 7.4 & $4.62 \mathrm{E}-13$ & $3.26 \mathrm{E}-19$ & $3.69 \mathrm{E}-13$ & $1.90 \mathrm{E}-14$ & $4.76 \mathrm{E}-14$ & 7.07E-07 & 0.511 & 7.766 & 0.399 & 24.321 & 0.000 & 6.15 \\
\hline \multicolumn{14}{|l|}{ Pierina } \\
\hline P452 & 9.5 & $5.37 \mathrm{E}-13$ & $3.83 \mathrm{E}-19$ & $4.50 \mathrm{E}-13$ & $1.78 \mathrm{E}-14$ & $5.08 \mathrm{E}-14$ & 7.14E-07 & 0.516 & 8.851 & 0.350 & 30.268 & 0.000 & 6.21 \\
\hline \multicolumn{14}{|c|}{ Magmatic-hydrothermal alunite } \\
\hline Thermally Released & & & & & & & & 0.13 & 10.02 & 0.03 & 258.16 & 0.000 & \\
\hline \multicolumn{13}{|l|}{ Tambo Stage 2} & \\
\hline T01a & 8.0 & $1.49 \mathrm{E}-12$ & $1.51 \mathrm{E}-19$ & $2.18 \mathrm{E}-12$ & $6.87 \mathrm{E}-15$ & $2.35 \mathrm{E}-13$ & $1.01 \mathrm{E}-07$ & 0.073 & 9.272 & 0.029 & 216.270 & 0.000 & 0.67 \\
\hline \multicolumn{14}{|l|}{ Pierina } \\
\hline P241 & 10.7 & $4.03 \mathrm{E}-13$ & $1.03 \mathrm{E}-19$ & $4.46 \mathrm{E}-13$ & $1.34 \mathrm{E}-15$ & 4.14E-14 & $2.55 \mathrm{E}-07$ & 0.184 & 10.775 & 0.032 & 300.046 & 0.000 & 2.05 \\
\hline \multicolumn{14}{|l|}{ Tapajós } \\
\hline $16 / 18\left(200{ }^{\circ} \mathrm{C}-1\right)$ & 7.0 & $1.32 \mathrm{E}-13$ & $1.93 \mathrm{E}-18$ & $4.23 \mathrm{E}-14$ & $1.35 \mathrm{E}-16$ & $4.55 \mathrm{E}-15$ & $1.47 \mathrm{E}-05$ & 10.598 & 9.288 & 0.030 & 975.139 & 0.001 & 52.95 \\
\hline $16 / 18\left(200{ }^{\circ} \mathrm{C}-2\right)$ & 7.0 & $3.32 \mathrm{E}-13$ & $4.91 \mathrm{E}-18$ & $1.40 \mathrm{E}-13$ & $4.85 \mathrm{E}-16$ & $1.61 \mathrm{E}-14$ & $1.48 \mathrm{E}-05$ & 10.695 & 8.740 & 0.030 & 684.131 & 0.160 & 53. \\
\hline $16 / 18\left(200{ }^{\circ} \mathrm{C}-3\right)$ & 7.0 & $2.50 \mathrm{E}-15$ & $3.61 \mathrm{E}-20$ & $2.50 \mathrm{E}-16$ & $7.30 \mathrm{E}-19$ & $1.91 \mathrm{E}-17$ & $1.44 \mathrm{E}-05$ & 10.439 & 13.082 & 0.038 & 3418.042 & & 52.1 \\
\hline Crush-released & & & & & & & & 0.45 & 10.79 & 0.04 & 65.88 & 0.000 & \\
\hline \multicolumn{14}{|l|}{ Tambo Stage 2} \\
\hline T01a & 8.0 & $8.61 \mathrm{E}-14$ & $4.72 \mathrm{E}-20$ & $4.76 \mathrm{E}-13$ & $1.55 \mathrm{E}-15$ & 4.11E-14 & $5.49 \mathrm{E}-07$ & 0.397 & 11.574 & 0.038 & 55.479 & 0.000 & \\
\hline \multicolumn{13}{|l|}{ Pierina } & \\
\hline P241 & 10.7 & $5.03 \mathrm{E}-14$ & $3.56 \mathrm{E}-20$ & $2.04 \mathrm{E}-13$ & $6.60 \mathrm{E}-16$ & $2.04 \mathrm{E}-14$ & 7.08E-07 & 0.511 & 10.003 & 0.032 & 76.283 & 0.000 & \\
\hline \multicolumn{14}{|l|}{ Tapajós } \\
\hline $16 / 18$ & 7.0 & $1.81 \mathrm{E}-14$ & $3.29 \mathrm{E}-20$ & $2.53 \mathrm{E}-14$ & $8.10 \mathrm{E}-17$ & $2.72 \mathrm{E}-15$ & $1.82 \mathrm{E}-06$ & 1.313 & 9.305 & 0.030 & 223.679 & 0.004 & \\
\hline
\end{tabular}

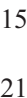

All samples except Tapajós calculated on assumption of mixture of crustal and magmatic He Tapajós assumed to be a mixture of crustal and mantle/hot-spot He Ra is the ${ }^{3} \mathrm{He} /{ }^{4} \mathrm{He}$ of atmosphere $=1.384 \times 10^{-6}$.

a Approximate ratio from abundance of $\mathrm{He}$ and $\mathrm{Ar}$ concentrations of Table 1.

b Calculated on assumption that crustal $\mathrm{R} / \mathrm{Ra}=0.02$, magmatic $\mathrm{R} / \mathrm{Ra}=8.00$, and mantle/hot-spot $\mathrm{R} / \mathrm{Ra}=20.00$. 
All alunite samples exhibited three types of fluidinclusion occurrences. Type 1 primary inclusions are elongate parallel to the alunite $\mathrm{c}$ axis and are commonly concentrated at micrometer to submicrometer crystal-domain boundaries (Fig. 1a-c). These boundaries are defined by a change in contiguous optical properties and epitaxial growth of alunite in a subtly different crystal orientation in otherwise massive alunite. Type 2 primary inclusions are aligned parallel to surfaces of mineral deposition, such as along growth bands of plumose plates and tabular blades, and are elongate perpendicular to the surface of mineral deposition (Fig. 1e). Type 3 inclusions are randomly dispersed, somewhat elongate, without preferred orientation or location, but are always within the interiors of optically definable crystal domains (Fig. 1f). Planes of secondary fluid inclusions are extremely rare in coarse-grained magmatic-steam alunite. Daughter minerals, except hematite, were absent from the gas-rich inclusions, and could not be positively identified within rare, extremely small, liquid-rich inclusions. Primary hematite is common in alunite both as solid inclusions (Fig. 1d) and as nucleating centers for fluid inclusions (Fig. 1a).

\section{Analytical methods}

The compositions of alunite inclusion fluids released both by crushing the sample and by heating in vacuo to $200{ }^{\circ} \mathrm{C}$ were determined. Crushing the sample presumably released gas from larger primary(?) and predominantly secondary fluid inclusions. Heating the sample presumably yielded gas predominantly from the submicrometer primary fluid inclusions. Whereas the crush-released inclusion fluids have a "postdeposition of alunite" component contained in secondary inclusions, the thermally released inclusion fluids best represent the composition of the alunite parental fluid. The "postdeposition of alunite" component, however, is thought to be intimately related to the fluids responsible for the formation of alunite, and the component is not a younger or modern contaminant gas.

The $1.87 \mathrm{Ga}$ alunite from Tapajós, Brazil, that was examined here also was used by Landis et al. (this Volume) to define the He and Ar diffusion parameters in alunite, and to evaluate the long-term preservation of the composition of the fluids trapped in fluid inclusions in alunite. The Landis et al. study showed that the original gas contents of the fluids, including $\mathrm{He}$ and $\mathrm{Ar}$ and their isotopes, have remained trapped in the fluid inclusions for nearly $2.0 \mathrm{Ga}$. Likewise, the data for much younger ( 23 to $2 \mathrm{Ma}$ ) alunite examined in this study indicate retention of the initial gas compositions.

A typical sample for analysis consisted of several ethanol-washed pieces of alunite, 0.5 to $1.0 \mathrm{~cm}$ on a side, totaling 4 to $30 \mathrm{~g}$. The sample was crushed offline in a stainless steel tube sealed under vacuum, returned to the manifold, and the gases were extracted and analyzed. The sample then was heated in the crush tube to $200{ }^{\circ} \mathrm{C}$ for $60 \mathrm{~min}$, and the evolved gases were analyzed. These extracted gases were analyzed both by a dynamically pumped quadrupole mass spectrometer (QMS: Pfeiffer Vacuum models Prisma and 410) for active-gas mixtures, and by a static high-resolution sector mass spectrometer (MAP: Mass Analyzer Products MAP 215-50) and QMS (in static mode) for noble-gas isotopic and elemental compositions. Analyzed concentrations of $\mathrm{N}_{2}, \mathrm{O}_{2}$, Ar, $\mathrm{H}_{2}, \mathrm{H}_{2} \mathrm{O}, \mathrm{H}_{2} \mathrm{~S}, \mathrm{SO}_{2}, \mathrm{HCl}, \mathrm{HF}, \mathrm{CH}_{4}, \mathrm{CO}_{2}, \mathrm{CO}$, and $\mathrm{He}$ were determined quantitatively by interpretation of QMS mass spectra and intensities. Mass spectra were corrected for background, specific ionization sensitivity relative to nitrogen, ion fragmentation, and for isobaric overlap of peaks with nominally identical atomic or molecular mass by a matrix solution to linear equations as reported by Landis and Hofstra (1991). The MAP analyses of $\mathrm{He}$ and $\mathrm{Ne}$ and their isotopes were performed separately after cryogenic separation on the same sample. Argon isotopic

\footnotetext{
Notes to Table 3:

${ }^{a}$ Ratio temperatures calculated from thermodynamic relations in Giggenbach (1997): $\log \left[\mathrm{CO}_{2} / \mathrm{H}_{2} \mathrm{~S}\right]=0.0168 T-9.83+3990 /(T+273)$; $\log$ $\left[\mathrm{CH}_{4} / \mathrm{CO}_{2}\right]=4625 /(T+273)-10.4 ;$ and $\log \left[\mathrm{CH}_{4} / \mathrm{H}_{2} \mathrm{~S}\right]=(0.0168 T)-20.23+(8615) /(T+273)$.

${ }^{\mathrm{b}}$ Correspondence temperature $(C T)$ as defined in Symonds et al. (1994) and calculated with SOLVGAS (Symonds and Reed, 1993). $T\left({ }^{\circ} \mathrm{C}\right)$ is approximate temperature of equilibrium between major gas species, defined when mole concentration measured and predicted from thermochemical calculations are within 10\%. Hyphen indicates a range in temperature and a forward slash reports CT for two subgroups of gas species not in equilibrium with each other as discussed in the text.
} 
Table 3

Gas ratios from Table 1 data

\begin{tabular}{|c|c|c|c|c|c|c|c|c|c|}
\hline Sample & $\mathrm{N}_{2} / \mathrm{Ar}$ & $\mathrm{H}_{2} \mathrm{~S} / \mathrm{SO}_{2}$ & $\begin{array}{l}\log \\
\left(\mathrm{CO}_{2} / \mathrm{H}_{2} \mathrm{~S}\right)\end{array}$ & $T\left({ }^{\circ} \mathrm{C}\right)^{\mathrm{a}}$ & $\begin{array}{l}\log \\
\left(\mathrm{CH}_{4} / \mathrm{CO}_{2}\right) \\
\end{array}$ & $T\left({ }^{\circ} \mathrm{C}\right)^{\mathrm{a}}$ & $\begin{array}{l}\log \\
\left(\mathrm{CH}_{4} / \mathrm{H}_{2} \mathrm{~S}\right)\end{array}$ & $T\left({ }^{\circ} \mathrm{C}\right)^{\mathrm{a}}$ & $C T\left({ }^{\circ} \mathrm{C}\right)^{\mathrm{b}}$ \\
\hline \multicolumn{10}{|l|}{ Magmatic-steam } \\
\hline \multicolumn{10}{|l|}{ Thermally released } \\
\hline \multicolumn{10}{|l|}{ Marysvale } \\
\hline M939a2 & 0.0 & 0.00 & & & 0.51 & 151 & & & 610 \\
\hline M939a3 & 96.0 & 0.00 & & & 0.18 & 164 & & & $515 / 910$ \\
\hline M939a4 & 109.6 & 0.00 & & & 0.08 & 168 & & & 620 \\
\hline M341a & 79.6 & 0.00 & & & -0.05 & 174 & & & \\
\hline M341b & 13.5 & 0.11 & 4.00 & 526 & -1.48 & 245 & 2.52 & 927 & $325 / 1050$ \\
\hline \multicolumn{10}{|l|}{ Cactus } \\
\hline Cactus 2 & 133.9 & 0.24 & 3.46 & 472 & -1.58 & 251 & 1.88 & 866 & $332-470$ \\
\hline \multicolumn{10}{|l|}{ Tambo Stage 3} \\
\hline $\mathrm{T} 02 \mathrm{~b}$ & 7.9 & 0.39 & 2.82 & 400 & -0.97 & 217 & 1.85 & 863 & 390 \\
\hline \multicolumn{10}{|c|}{ Tambo-banded alunite } \\
\hline Т08a & 3.7 & 0.02 & 4.43 & 566 & -0.81 & 210 & 3.62 & 1024 & 670 \\
\hline \multicolumn{10}{|l|}{ Pierina } \\
\hline P452 & 42.2 & 0.89 & 4.46 & 568 & -1.75 & 262 & 2.71 & 944 & $530-550$ \\
\hline \multicolumn{10}{|l|}{ Crush-released } \\
\hline \multicolumn{10}{|l|}{ Marysvale } \\
\hline M939a1 & 0.0 & & & & 0.22 & 162 & & & \\
\hline M341 & 49.5 & & & & -1.50 & 247 & & & \\
\hline M341 & 41.1 & & & & -1.13 & 226 & & & \\
\hline M341 & 38.3 & & & & -0.97 & 218 & & & \\
\hline \multicolumn{10}{|l|}{ Cactus } \\
\hline Cactus A & 80.0 & & & & 0.15 & 166 & & & \\
\hline Cactus 1 & 79.7 & & & & 0.15 & 166 & & & \\
\hline \multicolumn{10}{|l|}{ Tambo Stage 3} \\
\hline $\mathrm{T} 02 \mathrm{~b}$ & 44.1 & 0.48 & 3.27 & 452 & -0.70 & 204 & 2.56 & 931 & \\
\hline \multicolumn{10}{|l|}{ Tambo-banded alunite } \\
\hline T08a & 34.2 & 0.51 & 2.71 & 387 & -0.90 & 214 & 1.81 & 859 & \\
\hline KB-02a Early & 19.8 & 0.42 & 2.09 & 281 & -0.58 & 198 & 1.51 & 829 & \\
\hline KB-02a Late & 17.0 & 0.32 & 2.15 & 295 & -0.43 & 191 & 1.72 & 850 & \\
\hline KB-02b Early & 17.8 & 0.18 & 2.44 & 348 & -0.33 & 186 & 2.11 & 888 & \\
\hline KB-02b Late & 33.6 & 1.37 & 1.60 & 214 & -0.35 & 187 & 1.25 & 205 & \\
\hline \multicolumn{10}{|l|}{ Pierina } \\
\hline P452 & 50.7 & & & & -0.62 & 200 & & & \\
\hline \multicolumn{10}{|c|}{ Magmatic-hydrothermal } \\
\hline \multicolumn{10}{|c|}{ Thermally released } \\
\hline \multicolumn{10}{|l|}{ Tambo Stage 2} \\
\hline T01a & 9.8 & 4.83 & 2.44 & 348 & -1.52 & 248 & 0.93 & 766 & $280 / 820$ \\
\hline \multicolumn{10}{|l|}{ Pierina } \\
\hline P241 & 28.3 & 0.75 & 3.48 & 474 & -1.66 & 256 & 1.82 & 860 & 515 \\
\hline \multicolumn{10}{|l|}{ Tapajos } \\
\hline $16 / 18\left(200{ }^{\circ} \mathrm{C}-1\right)$ & 0.3 & 1.70 & 3.32 & 458 & -1.49 & 246 & 1.83 & 860 & $480 / 1160$ \\
\hline $16 / 18\left(200{ }^{\circ} \mathrm{C}-2\right)$ & 28.3 & 3.11 & 2.89 & 409 & -0.77 & 207 & 2.12 & 889 & \\
\hline Crush-released & & & & & & & & & \\
\hline Tambo & & & & & & & & & \\
\hline T01a & 33.4 & 0.53 & 2.90 & 410 & -0.89 & 213 & 2.02 & 879 & \\
\hline Pierina & & & & & & & & & \\
\hline P241 & 47.2 & 0.74 & 2.96 & 418 & -0.22 & 182 & 2.74 & 947 & \\
\hline Tapajos & & & & & & & & & \\
\hline $16 / 18$ & 96.3 & 4.25 & 1.66 & 214 & 0.43 & 154 & 2.09 & 886 & \\
\hline
\end{tabular}


analyses by MAP or QMS $\left({ }^{40} \mathrm{Ar} /{ }^{36} \mathrm{Ar}\right)$ were not possible in the early development stages of the Denver USGS noble-gas laboratory. With completed instrument development, data for $\mathrm{Ar}, \mathrm{Kr}$, and $\mathrm{Xe}$ will be included in future investigations.

As discussed in Landis et al. (this Volume), the two-step crushing and heating extraction process released nearly all of the gas in the fluid inclusions. In most instances, crushing yielded only a small fraction (ca. 5-15\%) of gas released subsequently by heating. Maintaining the temperature of alunite at 200 ${ }^{\circ} \mathrm{C}$ for $1 \mathrm{~h}$ released gas entrapped in abundant submicrometer primary inclusions. The high ratio of the volume of vapor/liquid ( $\approx$ low density) observed in the optical examination of fluid inclusions implies that gas from submicrometer inclusions was released largely by thermal expansion of alunite and less by fluid-inclusion decrepitation. The amount and nature of gas released from 'dark' regions is unknown, but is presumably small, given their small volume percentage in alunite. The sustained heating at $200{ }^{\circ} \mathrm{C}$ did not release gas generated by thermal decomposition of alunite (Landis et al., this Volume).

The compositions of gas from crush-released fluid potentially contain large amounts of extraneous gas components trapped, subsequent to alunite formation, along fractures and planes of secondary inclusions, whereas thermally released gas compositions most likely represent the volatiles that were originally trapped during alunite crystallization. Although these methods do not yield a clean separation of gases between primary and secondary inclusion fluids, the fluids are nonetheless predominantly one or the other. QMS analytical uncertainty is typically $\pm 0.5 \%$, with calibration and other error propagation yielding a total estimated error of $<2 \%$. The QMS detection limit is $<10 \mathrm{ppb} \mathrm{v/V} \mathrm{(parts} \mathrm{per} \mathrm{billion} \mathrm{by} \mathrm{volume} \mathrm{or} \mathrm{ppbV;}$ also mole fraction) of total gas. Total procedural, calibration, and instrumental erros for MAP analyses are $\pm 0.5 \%$ to no more than $\pm 0.8 \%$ ( $1 \sigma$ as percent (\%) of mean).

\section{Results for fluid-inclusion gas chemistry}

Gas data from heating 16 and crushing 13 samples of magmatic-steam and magmatic-hydrothermal alunite from five localities are reported in Tables 1 and 2.
Analyses of $\mathrm{He}$ and $\mathrm{Ne}$ isotopes by MAP ion counting, as well as important calculated ratios, are also given (Tables 2 and 3). Data are grouped by inferred environment of alunite formation. A few generalizations are possible from Table 1 . The order of gas abundance for magmatic-steam fluids is $\mathrm{H}_{2} \mathrm{O}>\mathrm{H}_{2}>\mathrm{N}_{2}>\mathrm{CO} \gg \mathrm{CO}_{2}>\mathrm{Ar}>\mathrm{CH}_{4} \gg \mathrm{O}_{2}>\mathrm{HF}>\mathrm{SO}_{2}>$ $\mathrm{He}>\mathrm{HCl}>\mathrm{H}_{2} \mathrm{~S}$. The order of gas abundance for magmatic-hydrothermal fluids is $\mathrm{H}_{2} \mathrm{O} \gg \mathrm{H}_{2}>\mathrm{CO}_{2} \gg$ $\mathrm{N}_{2}>\mathrm{HF} \gg \mathrm{CH}_{4}>\mathrm{Ar}>\mathrm{CO}>\mathrm{O}_{2}>\mathrm{HCl}>\mathrm{H}_{2} \mathrm{~S}>\mathrm{SO}_{2}>\mathrm{He}$.

Magmatic-steam fluids are the most volatile-rich and average about $\geq 20$ times the $\mathrm{N}_{2}, \mathrm{O}_{2}$, and $\mathrm{Ar}, \geq 2$ times the $\mathrm{H}_{2}$, and about half the $\mathrm{H}_{2} \mathrm{O}$ content of magmatic-hydrothermal fluids. Magmatic-steam fluids are $\mathrm{SO}_{2}$-dominant, with $\mathrm{SO}_{2} \gg \mathrm{H}_{2} \mathrm{~S}$ (average $\mathrm{SO}_{2}$ / $\mathrm{H}_{2} \mathrm{~S} \approx 202$ ), whereas magmatic-hydrothermal fluids have $\mathrm{SO}_{2} \leq \mathrm{H}_{2} \mathrm{~S}$ (average $\mathrm{SO}_{2} / \mathrm{H}_{2} \mathrm{~S} \approx 0.7$ ). Concentrations of sulfur species of both fluids are low (tens to hundreds of ppm V), but are typical of the results obtained from studies of fluid-inclusion gases in other deposits (Landis and Rye, 1989; Goldfarb et al., 1989; Hofstra et al., 1991; Landis and Hofstra, 1991; Plumlee et al., 1994). Magmatic-steam fluids are enriched in $\mathrm{HCl}$, but contain less $\mathrm{HF}$ relative to magmatic-hydrothermal fluids. Magmatic-hydrothermal fluids seem to have lost more $\mathrm{He}$, which is highly mobile. It was possible to measure He routinely only in magmatic-steam fluids (to concentrations as low as $10 \mathrm{ppm} \mathrm{V}$ by QMS methods). The MAP, with about $10^{6}$ more sensitivity, was unable to detect $\mathrm{He}$ in some magmatic-hydrothermal fluids. Some Marysvale magmatic-steam alunite inclusion fluids, with large $\mathrm{He}$ contents, have only $\mathrm{SO}_{2}$ as a sulfur gas. Methane, $\mathrm{CO}_{2}$, and especially $\mathrm{CO}$ are significantly elevated in magmatic-steam relative to magmatic-hydrothermal fluids. Both fluid types contain exceptionally high amounts of $\mathrm{H}_{2}$, in amounts never before detected in either fluid-inclusion gas of hydrothermal mineral deposits (Landis and Rye, 1989; Landis and Hofstra, 1991; Graney and Kesler, 1995) or in volcanic emanations (Symonds et al., 1994). The $\mathrm{N}_{2} / \mathrm{Ar}$ ratios of all fluids (Table 3) are not those of atmospheric or air-saturated waters (ASW), and He contents exceed the solubility limits in meteoric water by $1 \times 10^{5}$ to $>1 \times 10^{8}$; the data preclude a significant component of atmospheric gases in either magmatic-steam or magmatic-hydrothermal fluids. As discussed below, most components of these gas mixtures are not in 
thermodynamic equilibrium. Isotopic data for both $\mathrm{He}$ and $\mathrm{Ne}$ indicate a mixture of nonatmospheric radiogenic and nucleogenic ${ }^{4} \mathrm{He}_{-}-{ }^{21} \mathrm{Ne}-{ }^{22} \mathrm{Ne}$ crustal components, and ${ }^{3} \mathrm{He}-{ }^{20} \mathrm{Ne}$-enriched mantle sources (Table 2) in fluids for both magmatic-hydrothermal and magmatic-steam alunite.

\section{Discussion}

Numerous authors have discussed models for the nature of magmatic-steam and magmatic-hydrothermal fluids (e.g., Rye et al., 1992; Rye, 1993; Rye, this Volume; Hedenquist and Lowenstern, 1994; Fournier, 1999). The data for gas offer the opportunity to compare the composition of the parental fluids from each genetic type of alunite and to infer the differences in their environments of deposition. Insofar as current models of fluid evolution are correct, the gas data offer an opportunity to make a comparison between the composition of low-density fluids (magmatic-steam environment) that were derived directly from a magma, and the composition of the condensed evolved magmatic vapor fluids (magmatic-hydrothermal environment) that equilibrated with crystallized igneous rocks, formed large amounts of sulfuric acid from disproportionation of $\mathrm{SO}_{2}$, and ultimately mixed with meteoric water.

\subsection{Thermally and crush-released inclusion fluids}

\subsubsection{Atmospheric gases in the hydrothermal fluids}

The data obtained by crushing presumably are for a bulk composition that includes the contributions of multiple generations of fluids trapped along secondary inclusion planes and crystal boundaries, together with a lesser compositional contribution from the fluids of submicron-sized primary inclusions. The gas contents of rare larger primary fluid inclusions opened by crushing are insignificant to the total amount of gas released in the crushing procedure. As demonstrated by the detailed studies of Tapajós alunite (Landis et al., this Volume), the composition of the gas in fluids released by crushing can differ from the composition released thermally. The crush-released gas shows no evidence that the fluids contain an atmospheric

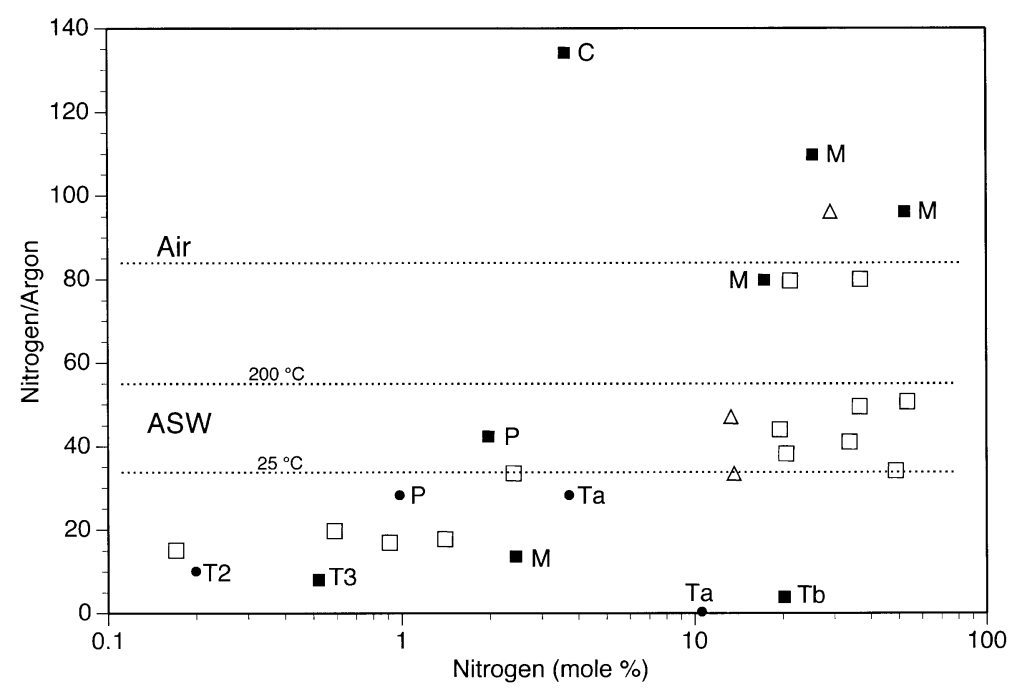

Fig. 2. Plot of $\mathrm{N}_{2} /$ Ar versus mole $\% \mathrm{~N}_{2}$ in fluids, showing values of atmospheric gases (=Air or Atm) and air-saturated water (ASW) at different temperatures. Solid symbols are compositions of thermally released fluids; open symbols are compositions of crush-released fluids. Magmaticsteam fluids=square, and magmatic-hydrothermal fluids=solid circle or triangle. Individual data-point labels used in this and subsequent plots are $\mathrm{M}=$ Marysvale, $\mathrm{C}=$ Cactus, $\mathrm{P}=$ Pierina, $\mathrm{Ta}=$ Tapajós, and $\mathrm{T} 2=$ Tambo Stage 2 alunite, $\mathrm{T} 3=$ Tambo Stage 3 alunite, and $\mathrm{Tb}=\mathrm{Tambo} \mathrm{Banded}$ alunite. The $\mathrm{N}_{2} / \mathrm{Ar}$ of atmosphere and the ASW values (dotted lines) increase from $38.4\left(25^{\circ} \mathrm{C}\right)$ to $44.9\left(100{ }^{\circ} \mathrm{C}\right)$ to $\sim 55\left(200{ }^{\circ} \mathrm{C}\right)$. The effect of atmospheric gas entrainment and air-saturated water (e.g., meteoric water) incursion into the magmatic fluids would produce $\mathrm{N}_{2} / \mathrm{Ar}$ ratios between those for air and ASW, depending on the temperature of air saturation. For typical meteoric water-hydrothermal fluid conditionsalmost all measured fluid compositions plot outside the range of those with possible Air-ASW contamination. 
component, and it is believed that the differences in compositions of fluids released by heating and crushing reflect real differences in the nature of primary (alunite parental fluids) and later hydrothermal fluids as incorporated by primary and secondary inclusions, respectively. The data obtained from inclusion fluids extracted by heating best characterize the composition of the primary hydrothermal fluids responsible for the precipitation of the host alunite.

As shown in Fig. 2 and Table 3, the absolute concentrations of $\mathrm{N}_{2}$ and $\mathrm{Ar}$ and the $\mathrm{N}_{2} / \mathrm{Ar}$ ratios of the fluid-inclusion gases indicate that neither atmosphere (Atm) nor air-saturated meteoric water (ASW) was a significant component of the fluids. Furthermore, the thermally released magmatic-steam and magmatic-hydrothermal inclusion fluids of alunite plot far from the compositions of atmosphere and air-saturated water at 25,50 , and $100{ }^{\circ} \mathrm{C}$ in the ternary $\mathrm{N}_{2}-\mathrm{O}_{2}-\mathrm{Ar}$ system (Fig. 3). Clearly, there is no

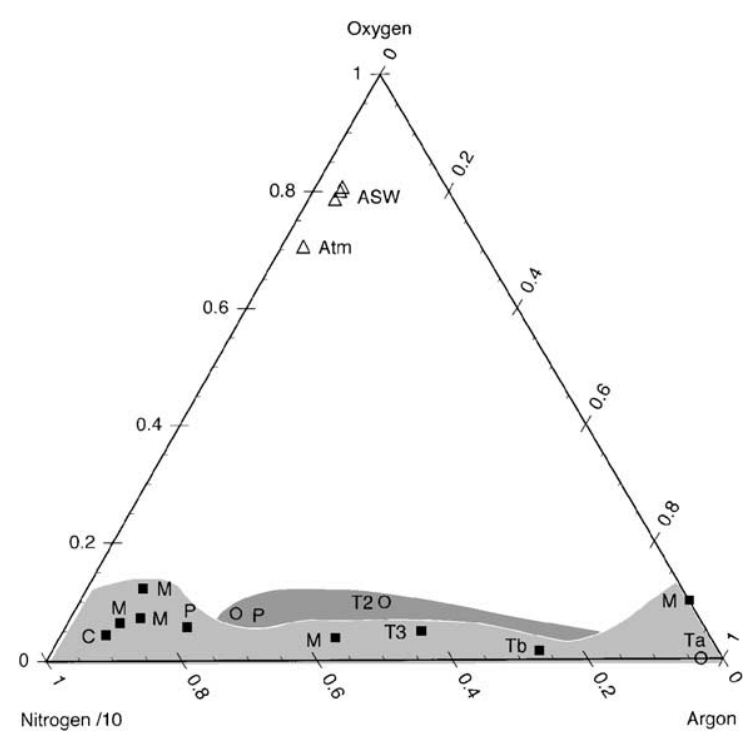

Fig. 3. Ternary plot of $\mathrm{N}_{2}-\mathrm{O}_{2}-\mathrm{Ar}$; Atm, ASW, and symbols are defined as in Fig. 2. The three ASW compositions, which were calculated for 25,50 , and $100{ }^{\circ} \mathrm{C}$, plot in the direction of increasing $\mathrm{N}_{2} / \mathrm{O}_{2}$ at higher temperature (Weiss, 1970, 1971). Only data for thermally released fluid are shown. The low oxygen content and the variable $\mathrm{N}_{2} / \mathrm{Ar}$ ratios preclude inclusion of atmospheric gas or dissolved ASW gas in either magmatic-steam or magmatic-hydrothermal fluids. Both fluid types show a broad overlap in composition fields, with magmatic-hydrothermal fluids having the lowest $\mathrm{N}_{2} /$ Ar. evidence of atmospheric gases in any of the inclusion fluids.

\subsubsection{Comparison with volcanic gases}

Volcanic gases are predominantly mixtures of $\mathrm{H}_{2} \mathrm{O}+\mathrm{CO}_{2}+\mathrm{SO}_{2}$, and the composition of alunite inclusion fluids can be compared with those for volcanic gas emanations (e.g., Rose et al., 1986; Symonds et al., 1994; Gerlach and McGee, 1994, 1998; Gerlach et al., 1999, 2002). The fluid-inclusion data for alunite are compared with the mixing line of $X_{\mathrm{H}_{2}} \mathrm{O}-X_{\mathrm{CO}_{2}}+\mathrm{SO}_{2}$ in Fig. 4, wherein a fluid with a composition down and to left of the mixing line for volcanic gases must have significant amounts of other gas species, such as $\mathrm{H}_{2}, \mathrm{CH}_{4}, \mathrm{CO}, \mathrm{N}_{2}$, or Ar. These species are not typical major components of volcanic gas emanations. The compositions of magmatic-steam fluids from Marysvale and Tambo are far removed from the mixing line in Fig. 4, and have a trajectory that suggests the presence of additional gases in the fluids. All data for magmatic-hydrothermal and the remaining magmatic-steam fluids plot sub-parallel to the mixing line, suggesting that other $\mathrm{C}$-bearing species, $\mathrm{N}$, or $\mathrm{H}$ are present. Data for the crush- and heat-released fluids plot within the same fields, implying that the secondary fluids are genetically linked to the primary fluids of alunite deposition.

\subsection{3. $\mathrm{N2}-\mathrm{Ar}-\mathrm{He}-\mathrm{Ne}$}

The $\mathrm{N}_{2}-\mathrm{Ar}-\mathrm{He}-\mathrm{Ne}$ concentrations and ratios, and the $\mathrm{He}$ and $\mathrm{Ne}$ isotopic compositions of fluids, identify the sources of components and the volatile separation and condensation events in the fluids (Giggenbach, 1997; Moore et al., 2001). This section gives examples of how such data may be used to investigate the details of fluid evolution. Giggenbach's $\mathrm{N}_{2}-\mathrm{Ar}-\mathrm{He}$ ternary plot (Fig. 5) can be a tool to recognize boiling and condensation in fluids, and to record the partitioning of gases between liquid and vapor in magmatic-steam and magmatic-hydrothermal fluids (Norman and Musgrave, 1994; Giggenbach, 1997; Moore et al., 2001). In Fig. 5, magmatic-steam fluids plot in a broad field of elevated $\mathrm{N}_{2}$ and $\mathrm{He}$ contents, whereas magmatic-hydrothermal fluids plot along the $\mathrm{N}_{2}-\mathrm{Ar}$ join. For all gases analyzed, with the exception of those in the Tapajós fluids, the $\mathrm{R} / \mathrm{Ra}$ $\left({ }^{3} \mathrm{He} /{ }^{4} \mathrm{He}_{\text {observed }} /{ }^{3} \mathrm{He} /{ }^{4} \mathrm{He}_{\text {air }}\right)$ of $\mathrm{He}$ points to a major (90 to $>98 \%$ ) component of crustal $\mathrm{He}(\mathrm{R} / \mathrm{Ra} \approx 0.02$, 


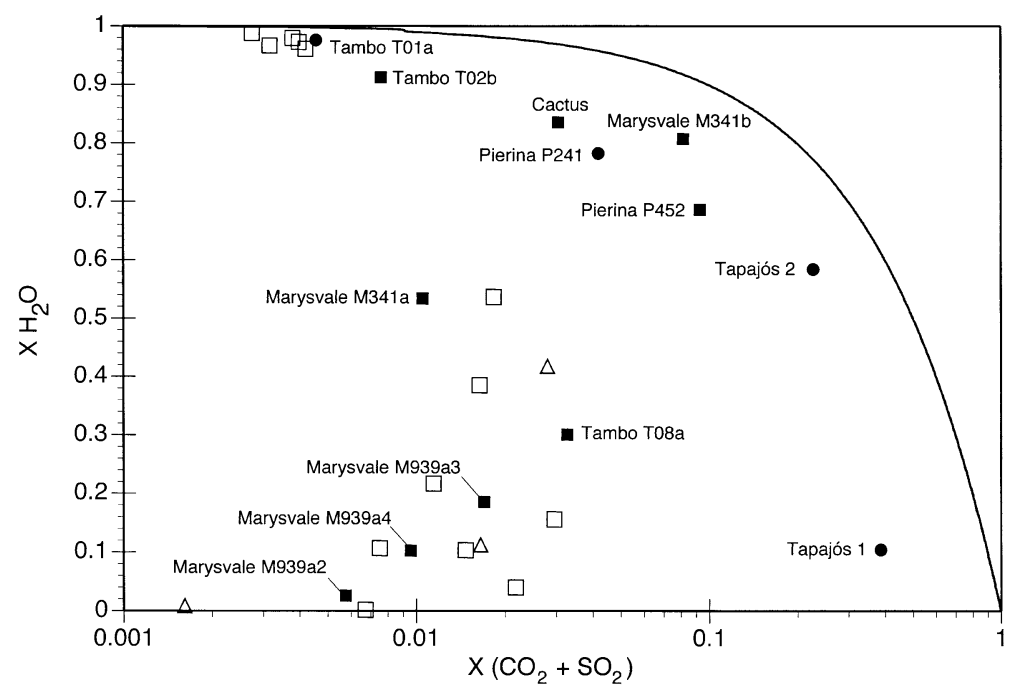

Fig. 4. Plot of alunite inclusion fluid $X_{\mathrm{H}_{2}} \mathrm{O}$ versus $X_{\mathrm{CO}_{2}+\mathrm{SO}_{2}}$ as mole fractions. These three gases typically dominate volcanic gas compositions, and data from active volcanoes plot close to the mixing curve shown by the solid line (Symonds et al., 1994, and references therein). Fluid compositions from this study that plot down and to the left of the mixing line contain increasing amounts of other gas species, such as $\mathrm{H}_{2}, \mathrm{CH}_{4}$, $\mathrm{CO}, \mathrm{N}_{2}, \mathrm{Ar}$, and $\mathrm{H}_{2} \mathrm{~S}$. Data for thermally released gas (solid symbols) from magmatic-hydrothermal fluids (circles) plot systematically near this mixing line, as do the gas data of about half of the magmatic-steam fluids (squares). The compositions of some Marysvale and Tambo magmatic-steam fluids are well removed from the mixing line, indicating that the fluids contain major amounts of other gas species. Data for crush-released fluid inclusions from both magmatic-steam and magmatic-hydrothermal alunite mimic the compositional data for the thermally released magmatic-steam fluid, suggesting that most of the crush-released fluids were either from the same inclusion populations or from different (secondary) populations whose compositions were similar to those in the thermally released primary fluids. Data labels are sample numbers in Table 1.

low $\left.{ }^{3} \mathrm{He} /{ }^{4} \mathrm{He}\right)$, mixed with a mantle-derived $\mathrm{He}$ component $\left(\mathrm{R} / \mathrm{Ra} \approx 8\right.$, higher $\left.{ }^{3} \mathrm{He} /{ }^{4} \mathrm{He}\right)$. Lack of oxygen in the fluids (Fig. 3), highly variable $\mathrm{N}_{2} / \mathrm{Ar}$, and composition tie-lines that do not project back to atmosphere or air-saturated water compositions indicate that this crustal $\mathrm{He}$ was not derived at shallow levels by mixing with meteoric water in either magmatic-steam or magmatic-hydrothermal fluids.

Whereas the fluids in Marysvale alunite, as characteristic of the end-member magmatic-steam environment, are rich in $\mathrm{He}$, the magmatic-hydrothermal fluids have little or no He. As seen in the evolution of gas compositions of fluids from the Tambo alunite sequence of Stage 2 (magmatic-hydrothermal) through Stage 3 (magmatic-steam), to Banded alunite (magmatic-steam), even the late-stage magmatic-steam fluids from Tambo are depleted in $\mathrm{He}$, a feature that suggests a different type of magmatic-steam environment than that at Marysvale. Whereas the He content of Marysvale magmaticsteam fluids is consistent with their derivation directly from a magma, the Tambo fluids show evidence of degassing after separation from a melt, such as would be expected to occur in liquid-phase magmatichydrothermal fluids below the brittle-ductile transition. Thus, the magmatic-steam fluids at Tambo were likely derived from flashed liquids below the brittleductile transition, and not directly from a magma as at Marysvale.

The plot of $\mathrm{R} / \mathrm{Ra}$ for $\mathrm{He}$ versus the $\mathrm{N}_{2} / \mathrm{Ar}$ ratio of thermally and crush-released fluids in Fig. 6 further develops the concepts portrayed on the $\mathrm{N}_{2}-\mathrm{Ar}-\mathrm{He}$ ternary diagram of Fig. 5 (Giggenbach, 1992). In the crush-released fluids, the abundances of secondary gases that have different compositions are greater than in the thermally released primary fluids. The tie-lines linking "paired" compositions for thermally and crush-released fluids from the same sample illustrate this point. The $\mathrm{R} / \mathrm{Ra}$ of the $\mathrm{He}$ differentiates $\mathrm{He}$ derived from mantle $\left({ }^{3} \mathrm{He}\right.$-enriched) versus crustal (strongly radiogenic, ${ }^{4} \mathrm{He}$-dominant) sources, whereas $\mathrm{N}_{2} /$ Ar ratios reflect a combination of sources and the processes of liquid-vapor-phase separation. In hydrothermal fluids, the gas/liquid partition coefficients for 


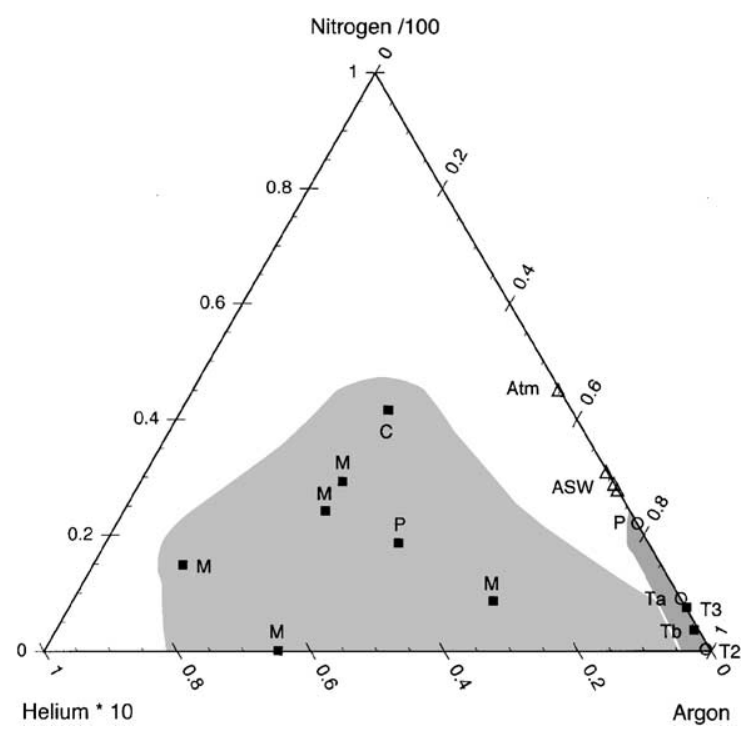

Fig. 5. Ternary plot of $\mathrm{N}_{2}-\mathrm{Ar}-\mathrm{He}$. Data-point labels, Atm, ASW, and other symbols are as defined in Fig. 2. The different values for ASW that are calculated at 25,50 , and $100{ }^{\circ} \mathrm{C}$ plot towards Atm with increase in temperature. Almost no He is present in magmatichydrothermal fluids, indicating that they have degassed and lost $\mathrm{He}$ as the fluids recondensed. The variable He content in magmaticsteam fluids exceeds the solubility limits for ASW, such as might occur during initial exsolution of fluids from a magma. The field for magmatic-steam fluid represents a mixture of magmatic and crustal $\mathrm{He}$, with gas chemistry modified by vapor-liquid phase fractionation. Thermally released data only are shown.

$\mathrm{N}_{2}$ and Ar differ by a factor of about 2, such that $\mathrm{N}_{2} /$ Ar of vapor will be approximately twice that of the liquid from which it separates (Weiss, 1970, 1971). Thus, condensed liquids will have lower $\mathrm{N}_{2} / \mathrm{Ar}$ ratios than their vapor counterpart. Thermally released fluids in Fig. 6 show a wide variation in $\mathrm{N}_{2} / \mathrm{Ar}$, from $<0.3$ to 134 , and have generally low $\mathrm{R} / \mathrm{Ra}$ (average of 0.15 ), thus requiring a large component of crustal He. The compositions of all magmatic-steam thermally released fluids, especially those from Marysvale alunite $(\mathrm{R} / \mathrm{Ra} \approx 0.05)$, plot near a crustal He-isotope value with a large range of $\mathrm{N}_{2} / \mathrm{Ar}$. This range in $\mathrm{N}_{2} / \mathrm{Ar}$ indicates that magmatic-steam fluids contain both condensed liquids and vapor. The maximum possible $\mathrm{N}_{2} / \mathrm{Ar}$ ratio of vapor separated by distillation processes from condensed meteoric water is about 110 , whereas the minimum $\mathrm{N}_{2} / \mathrm{Ar}$ of the liquid meteoric water residue is $\sim 15$ (Norman and Musgrave, 1994; Moore et al., 2001). The greater $\mathrm{N}_{2} /$ Ar ratios of crushreleased fluids observed in most samples compared to the ratios of the paired thermally released fluids most likely reflect late-stage, vapor-phase fluids trapped during the waning or post-crystallization stages of alunite deposition (cf. Norman and Musgrave, 1994; Giggenbach, 1997). The R/Ra variations in Fig. 6 reflect mixing of crustal and mantle $\mathrm{He}$ in the parental magma (Ozima and Podosek, 2002; Landis et al., this Volume). Compositions of magmatic-hydrothermal fluid plot entirely in the low $\mathrm{N}_{2} / \mathrm{Ar}$ ratio and higher $\mathrm{R} / \mathrm{Ra}$ corner of Fig. 6, in contrast to the data for magmatic-steam gas. These data are consistent with prior gas/species partitioning between liquid and vapor phases that resulted in increased $\mathrm{N}_{2} / \mathrm{Ar}$ ratios in the vapor, and are consistent with the direct addition of mantle-derived $\mathrm{He}$ to the vapor phase in the fluids represented by the crush-released gases.

The ${ }^{4} \mathrm{He} /{ }^{40} \mathrm{Ar}$ of these fluids (Table 2) can be approximated by the measurements of ${ }^{4} \mathrm{He}$ and total Ar, assuming that $\mathrm{Ar}$ is dominantly ${ }^{40} \mathrm{Ar}$ (295 $\mathrm{atm} \approx{ }^{40} \mathrm{Ar}{ }^{36} \mathrm{Ar} \gg 20,000 \mathrm{MORB}$; Ozima and Podosek, 2002). Almost all ${ }^{4} \mathrm{He}$ and ${ }^{40} \mathrm{Ar}$ are radiogenic, and the ${ }^{4} \mathrm{He} /{ }^{40} \mathrm{Ar}$ ratio is constant for a given $\mathrm{Th} / \mathrm{U}, \mathrm{K} / \mathrm{U}$, and duration of accumulation. A typical constant crustal production ratio of ${ }^{4} \mathrm{He} /{ }^{40} \mathrm{Ar}$ is about 2 to 6 (maximum of $\sim 102$ to 103 for MORB; Ozima and Igarashi, 2000; Ozima and Podosek, 2002), whereas ${ }^{4} \mathrm{He} /{ }^{40} \mathrm{Ar}$ is approximately 0 to 0.5 in magmatic-steam and magmatic-hydrothermal fluids. The ${ }^{4} \mathrm{He} /{ }^{40} \mathrm{Ar}$ of magmatic-steam gas is greater than that in magmatichydrothermal gas, and for both genetic types of alunite, the $\mathrm{R} / \mathrm{Ra}$ and ${ }^{4} \mathrm{He} /{ }^{40} \mathrm{Ar}$ ratios were larger for the crush- than the thermal-released gas. The content of mantle-derived He and $\mathrm{Ar}$ increased in the crushreleased fluids. Although the $\mathrm{R} / \mathrm{Ra}$ indicates $\mathrm{He}$ is predominantly crustal in origin, the ${ }^{4} \mathrm{He} /{ }^{40} \mathrm{Ar}$ ratio is not crustal production. During magmatic vapor separation from its parent magma, $\geq 90 \%$ of the He was 'lost' relative to Ar from the alunite-forming fluids.

Neon in magmas can be a complex mixture derived from terrestrial, evolved upper mantle (MORB-like), deeper and more primitive mantle plumes (OIB-like), and subducted crustal-atmospheric (recycled) sources (Ozima and Podosek, 2002). The unique isotopic signatures (Kennedy et al., 1990; Farley and Poreda, 1993; O'Nions and Ballentine, 1993; Ballentine and Barford, 2000; Ozima and Igarashi, 2000) for these different sources can permit recognition of the magmas that gave rise to magmatic fluids. The data 


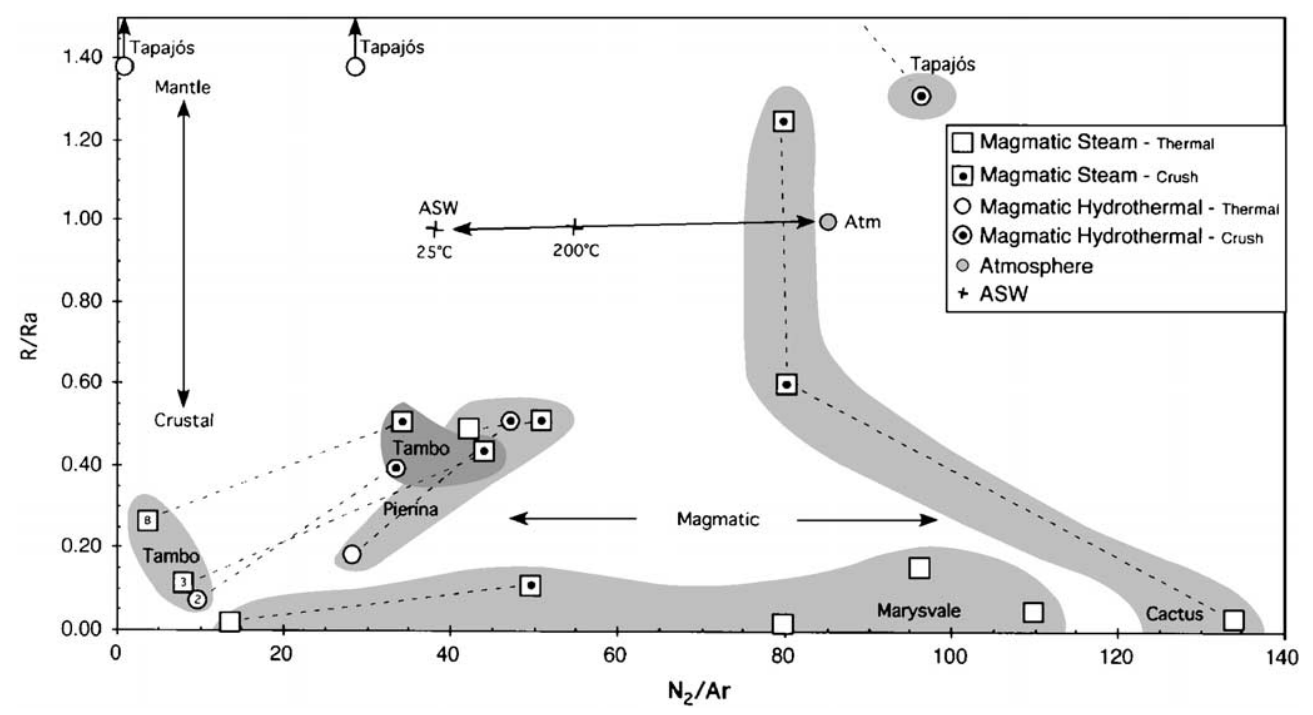

Fig. 6. Plot of $\mathrm{R} / \mathrm{Ra}$ versus $\mathrm{N}_{2} / \mathrm{Ar}$, where $\mathrm{R}={ }^{3} \mathrm{He} /{ }^{4} \mathrm{He}$ and $\mathrm{Ra}=\mathrm{R}$ (atmosphere $=1.384 \times 10^{-6}$ ). Helium $\mathrm{R} / \mathrm{Ra}$ varies with mixing between crustal $\mathrm{He}$

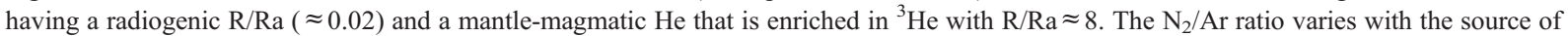
magma, history of boiling, volatile separation, and condensation of fluids; the ratio is controlled by the relative solubilities of $\mathrm{N}_{2}$ and Ar in condensed fluids, and by the Bunsen coefficients for liquid-gas partitioning for He isotopes, $\mathrm{N}_{2}$, and Ar. The plotted data exhibit highly variable magmatic $\mathrm{N}_{2} / \mathrm{Ar}$ and $\mathrm{He}$ isotope ratios that reflect these mixing-condensation-boiling processes. Tie-lines connect thermally and crush-released fluid compositions. Atm and ASW and other symbols are defined in Fig. 2. The crush-released fluids cannot be derived from the mixing of fluids compositionally similar to thermally released fluids with ASW because the measured He contents of alunite inclusion fluids are $\times 10^{5}$ to more than $\times 10^{8}$ those in ASW $\left(\approx 5-44 \mu \mathrm{cc} / \mathrm{kg} \mathrm{H}_{2} \mathrm{O}\right.$ STP). Thus, gas compositions in crush-released fluid most likely represent volatiles in hydrothermal fluids trapped shortly after alunite deposition. The legend identifies symbols used for magmatic-steam and magmatichydrothermal fluids. Symbols with solid circle centers are the compositions of crush-released gas, and the open symbols are for thermal release. Crush- and thermal-released fluid pairs from the same sample are connected with dashed tie-lines. Atm and $\mathrm{ASW}\left(\mathrm{N}_{2} / \mathrm{Ar}=38.4\right.$ at $25^{\circ} \mathrm{C}=55.1$ at $200{ }^{\circ} \mathrm{C}$ ) compositions are plotted for reference. A small ${ }^{3} \mathrm{He} /{ }^{4} \mathrm{He}$ isotopic fractionation between air and water is neglected. Compositions of Tapajós thermally released fluid plot off scale at $\mathrm{N}_{2} / \mathrm{Ar}=0.33$ and 28.26 and $\mathrm{R} / \mathrm{Ra}=10.6$ and 10.7 ratios, respectively.

are evaluated with a three-isotope plot of ${ }^{20} \mathrm{Ne} /{ }^{22} \mathrm{Ne}$ versus ${ }^{21} \mathrm{Ne} /{ }^{22} \mathrm{Ne}$ (Fig. 7). The Ne in magmatic-steam inclusion fluids $\left({ }^{20} \mathrm{Ne} /{ }^{22} \mathrm{Ne}=9.1-11.2\right)$ and magmatichydrothermal $\left({ }^{20} \mathrm{Ne} /{ }^{22} \mathrm{Ne}=8.7-13.1\right)$ alunite seems to be a mixture of a minor amount of nucleogenic crustal $\mathrm{Ne}$ in combination with a major amount of magmatic $\mathrm{Ne}$ that contains a MORB mantle component $\left({ }^{20} \mathrm{Ne} /{ }^{22} \mathrm{Ne} \approx 12.5\right)$ for the Tertiary fluids, and that contains an OIB mantle-plume component $\left({ }^{20} \mathrm{Ne} /{ }^{22} \mathrm{Ne} \geq 13\right)$ for the $1.87 \mathrm{Ga}$ Tapajós fluids. A more primitive OIB mantle-plume $\mathrm{Ne}$ isotopic signature at Tapajós is compatible with the less-evolved Proterozoic continental margin geological setting described by Juliani et al. (this Volume). The high concentrations of radioactive $\mathrm{U}, \mathrm{Th}$, and $\mathrm{K}$ in the crust, and the associated alpha and neutron decay products, induce nucleogenic production of $\mathrm{Ne}$ isotopes. In crustal nucleogenic processes, an increase in
${ }^{21} \mathrm{Ne}{ }^{22} \mathrm{Ne}$ from magmatic $\mathrm{Ne}$ at 0.029 involves the nucleogenic production of ${ }^{21} \mathrm{Ne}$ by ${ }^{18} \mathrm{O}(\alpha, \mathrm{n}){ }^{21} \mathrm{Ne}$ and ${ }^{24} \mathrm{Mg}(\mathrm{n}, \alpha){ }^{21} \mathrm{Ne}$, and $\mathrm{a}^{20} \mathrm{Ne} /{ }^{22} \mathrm{Ne}$ decrease from 9.82 by ${ }^{19} \mathrm{~F}(\alpha, \mathrm{n}){ }^{22} \mathrm{Ne}$ and $\left.{ }^{25} \mathrm{Mg}(\mathrm{n}, \alpha)\right)^{22} \mathrm{Ne}$. The paths of $\mathrm{Mg}$ production would be most important in rocks that have high $\mathrm{Mg}$ abundances, such as those in the lower crust and mantle. Both crustal nucleogenic processes are only weakly evident in the data in Fig. 7.

None of the $\mathrm{Ne}$ isotopic data in Fig. 7 are far removed from magmatic or atmospheric values. Both ${ }^{4} \mathrm{He}$ and ${ }^{21} \mathrm{Ne}$ should be produced in the upper crust by radiogenic decay and nucleogenic interactions at a nearly constant ratio (Kyser and Rison, 1982; Kennedy et al., 1990; O'Nions and Ballentine, 1993; Yatsevich and Honda, 1997). This production ratio, given typical upper crustal U-Th concentrations, is estimated to be ${ }^{4} \mathrm{He} /{ }^{21} \mathrm{Ne} \approx 2.1 \times 10^{7}$. The maximum ${ }^{4} \mathrm{He} /{ }^{21} \mathrm{Ne}$ in Table $2\left(3.5 \times 10^{3}\right)$ is four orders of 


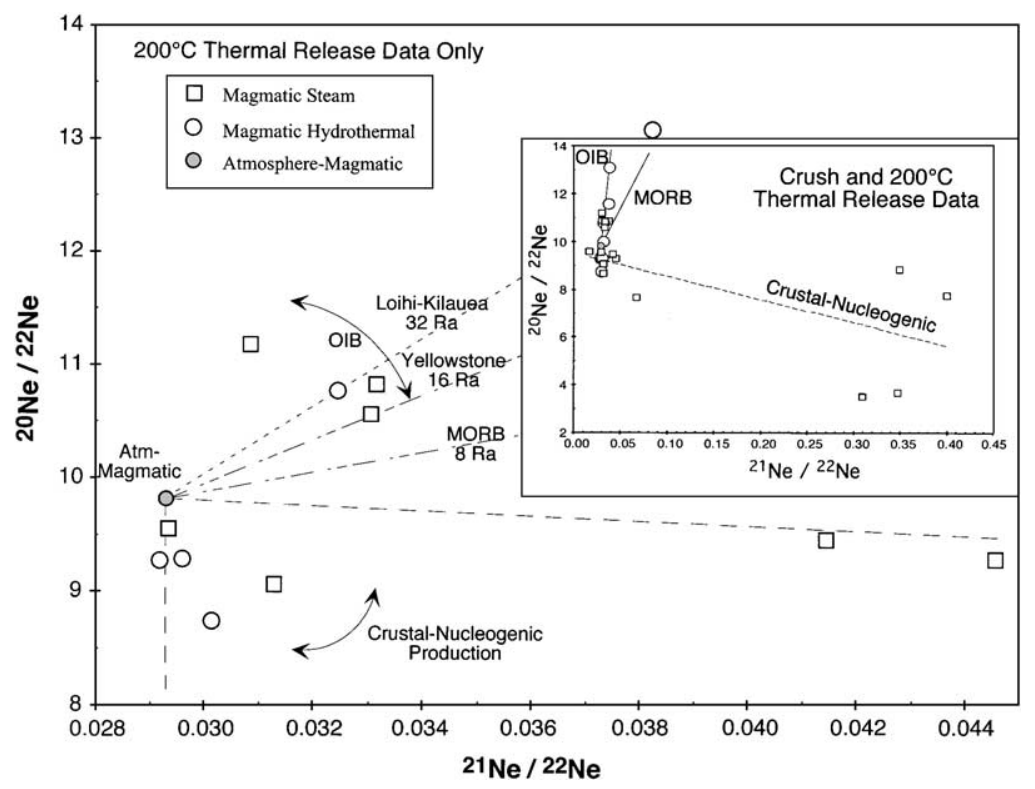

Fig. 7. Plot of ${ }^{20} \mathrm{Ne} /{ }^{22} \mathrm{Ne}$ versus ${ }^{21} \mathrm{Ne} /{ }^{22} \mathrm{Ne}$. Main plot is of data only for thermally released $\left(200{ }^{\circ} \mathrm{C}\right)$ fluid, and the insert shows at an expanded scale the data both for thermal and crush releases. Magmatic-atmospheric Ne, MORB (mid-oceanic ridge basalt; Honda et al., 1993), Yellowstone OIB (oceanic island basalt; Craig et al., 1978), and Loihi-Kilauea (Sarda et al., 1988) correlation lines, and the nucleogenic range of values are included for reference. The Ne is a mixture of both MORB and OIB with magmatic and crustal nucleogenic Ne.

magnitude less than crustal production, even given a low $\mathrm{R} / \mathrm{Ra}$ for crustal He. The $\mathrm{R} / \mathrm{Ra}$ of $\mathrm{He}$ appears to increase with ${ }^{21} \mathrm{Ne} /{ }^{22} \mathrm{Ne}$ ratios, yet incorporation of crustal He into the magmatic fluids does not seem to be accompanied by significant amounts of crustal Ne. Fluids of the three stages of Tambo alunite exhibit a general loss of $\mathrm{He}$ and a progressive increase in $\mathrm{R} / \mathrm{Ra}$ (i.e., more mantle-derived ${ }^{3} \mathrm{He}$ ) and a decrease in ${ }^{4} \mathrm{He} /{ }^{21} \mathrm{Ne}$ in the progression from magmatic-hydrothermal to magmatic-steam environments.

The combined $\mathrm{N}_{2}-\mathrm{Ar}-\mathrm{He}-\mathrm{Ne}$ data for magmatichydrothermal and magmatic-steam fluids suggest that: (1) alunite in these environments formed in the presence of two-phase fluids; (2) magmatic-steam fluids contained crustal $\mathrm{He}$ in amounts far larger than those derivable from ASW; (3) Ne was derived largely from magmatic and mantle sources, with only minor contributions from nucleogenic crustal sources; and (4) magmatic-hydrothermal fluids lost almost all of their $\mathrm{He}$ as a result of boiling and vapor-phase removal. Although these fluids exsolved at relatively shallow depths in the crust, their rare-gas isotopic compositions originated in sources located in lower crust and mantle rocks.

\subsection{Active-gas data}

Fluids from magmatic-steam and magmatic-hydrothermal alunite both contain similar amounts of $\mathrm{CO}_{2}$. The $\mathrm{CO}_{2}$ content varies inversely with $\mathrm{H}_{2} \mathrm{O}$ in magmatic-hydrothermal fluids, whereas $\mathrm{CO}_{2}$ varies positively with $\mathrm{H}_{2} \mathrm{O}$ in magmatic-steam fluids (Table 1). These relationships are consistent with the low $\mathrm{CO}_{2} / \mathrm{H}_{2} \mathrm{O}$ expected for magmatic-hydrothermal fluids, wherein $\mathrm{CO}_{2}$ content is controlled by its solubility in condensing fluids (e.g., magmatic gas scrubbing); in contrast, high $\mathrm{CO}_{2} / \mathrm{H}_{2} \mathrm{O}$ would be expected for magmatic-steam fluids that are released directly from a magma (Doukas and Gerlach, 1995; Zimbelman et al., 2000; Symonds et al., 2001). A plot showing the speciation of carbon gas among $\mathrm{CO}_{2}-\mathrm{CO}-\mathrm{CH}_{4}$ (Fig. 8 ) indicates that all magmatic-hydrothermal fluids are $\mathrm{CO}_{2}$-dominant, whereas only some magmatic-steam fluids are $\mathrm{CO}_{2}$-dominant. Marysvale magmatic-steam fluids in alunite show the greatest variation in speciation, with significant amounts of $\mathrm{CO}$ and $\mathrm{CH}_{4}$ in some samples.

For the Marysvale fluids in Fig. 8, a tie-line projected from the $\mathrm{CO}$ apex to the $\mathrm{CO}_{2}-\mathrm{CH}_{4}$ binary 


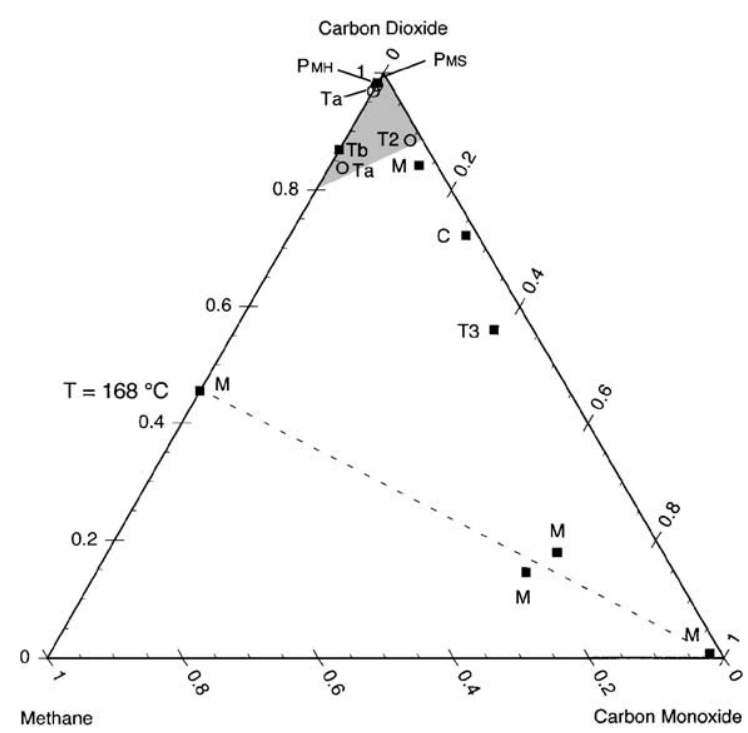

Fig. 8. Plot of $\mathrm{CO}_{2}-\mathrm{CO}-\mathrm{CH}_{4}$ relative abundances of magmatichydrothermal and magmatic-steam fluids. All magmatic-hydrothermal fluids are $\mathrm{CO}_{2}$-dominant. Magmatic-steam fluids contain more $\mathrm{CO}$ and $\mathrm{CH}_{4}$. Data for Marysvale alunite inclusion fluids suggest a constant $\mathrm{CH}_{4} / \mathrm{CO}_{2}$ ratio with an apparent equilibrium temperature of $168{ }^{\circ} \mathrm{C}$ (Giggenbach, 1997). Localities are indicated by letters as in Fig. 2 .

defines a $\mathrm{CH}_{4} / \mathrm{CO}_{2}$ ratio that equates to a calculated thermodynamic temperature of $168{ }^{\circ} \mathrm{C}$ (Giggenbach, 1997). Similar calculated temperatures based upon $\mathrm{CO}_{2} / \mathrm{H}_{2} \mathrm{~S}, \mathrm{CH}_{4} / \mathrm{CO}_{2}$, and $\mathrm{CH}_{4} / \mathrm{H}_{2} \mathrm{~S}$ gas ratios are tabulated in Table 3. These temperatures vary from $150-262{ }^{\circ} \mathrm{C}$ for $\mathrm{CH}_{4} / \mathrm{CO}_{2}$ of all fluids, $400-568{ }^{\circ} \mathrm{C}$ for $\mathrm{CO}_{2} / \mathrm{H}_{2} \mathrm{~S}$, and $860-1025{ }^{\circ} \mathrm{C}$ for $\mathrm{CH}_{4} / \mathrm{H}_{2} \mathrm{~S}$. The different calculated thermodynamic temperature ranges for each gas/species ratio indicate systematic disequilibrium gas speciation in the parent fluids. This disequilibrium is further evident in the discussion of SOLVGAS calculations in Section 6.4.

The $\mathrm{SO}_{2}-\mathrm{HCl}-\mathrm{H}_{2} \mathrm{~S}$ plot (Fig. 9) illustrates the $\mathrm{SO}_{2}$-dominant nature of magmatic-steam fluids over a range in $\mathrm{HCl}$ concentrations. Magmatic-hydrothermal fluids are consistently $\mathrm{H}_{2} \mathrm{~S}$-rich relative to magmaticsteam fluids. This preferential enrichment of reduced and oxidized sulfur gas/species in magmatic-hydrothermal and magmatic-steam fluids, respectively, is also shown in the $\mathrm{SO}_{2}-\mathrm{CO}_{2}-\mathrm{H}_{2} \mathrm{~S}$ plot in Fig. 10 . Fluids from both environments contain similar amounts of $\mathrm{CO}_{2}$. These observations require different redox states $\left(f \mathrm{O}_{2}\right.$ conditions $)$ for magmatic-steam and magmatic-hydrothermal fluids (cf. Giggenbach, 1997).

\subsection{Redox equilibrium and excess $H$ in alunite inclusion fluids}

The $\mathrm{H}_{2}-\mathrm{SO}_{2}-\mathrm{He}$ plot in Fig. 11 illustrates that both magmatic-steam and magmatic-hydrothermal fluids are $\mathrm{H}_{2}$-rich, and that Marysvale magmatic-steam and Tapajos magmatic-hydrothermal fluids in alunite differ in their $\mathrm{SO}_{2}$-to-He contents compared to each other and to fluids from other localities. These differences are consistent with different fluid histories at Marysvale, Tapajós and Pierina, Tambo, and Cactus as further discussed in Section 6.7.

It is well known that $\mathrm{H}_{2}$ will partition into the vapor phase during and after exsolution of fluids from a magma (Symonds and Reed, 1993). The alunite inclusion fluids are significantly more $\mathrm{H}_{2}$-rich $(0.2$ to $66 \mathrm{~mol} \%, \pm 1 \mathrm{~mol} \%$ ) than can be inferred from thermodynamic and $\log f \mathrm{O}_{2}$ relations, discussed below, or than has been reported for volcanic gas

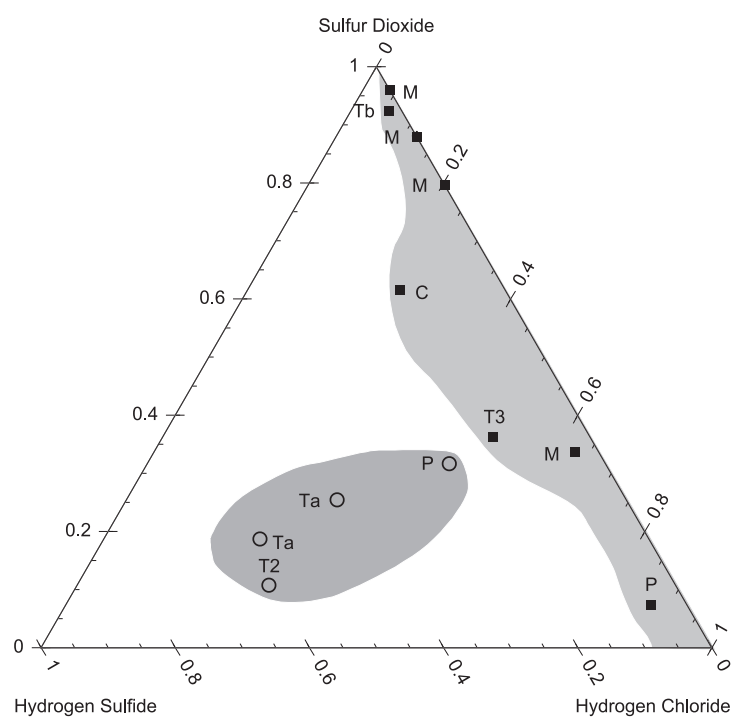

Fig. 9. Plot of $\mathrm{SO}_{2}-\mathrm{HCl}-\mathrm{H}_{2} \mathrm{~S}$ relative abundances in magmatichydrothermal and magmatic-steam fluids. Sulfur dioxide-dominant magmatic-steam fluids and $\mathrm{H}_{2} \mathrm{~S}$-dominant magmatic-hydrothermal fluids have different relative $\mathrm{HCl}$ contents. Magmatic-hydrothermal fluids exhibit a restricted range of relative $\mathrm{HCl}$ concentrations whereas the relative $\mathrm{HCl}$ concentrations of magmatic-steam fluids are highly variable and reach values approximately nine times those observed in magmatic-hydrothermal fluids. Localities are indicated by letters as in Fig. 2. 


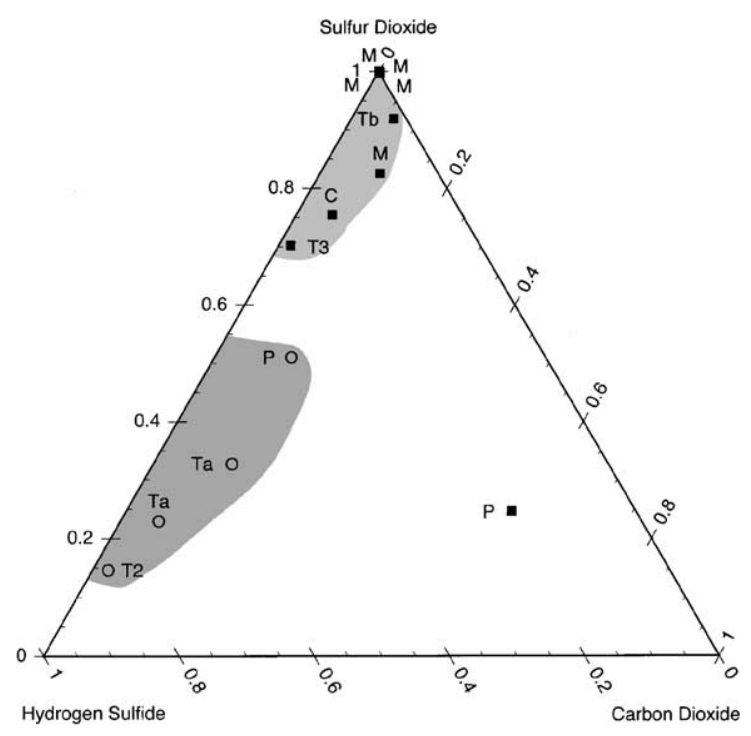

Fig. 10. Plot of $\mathrm{SO}_{2}-\mathrm{CO}_{2}-\mathrm{H}_{2} \mathrm{~S}$ relative abundances in magmatichydrothermal and magmatic-steam fluids, both of which contain similar relative $\mathrm{CO}_{2}$ concentrations but are readily distinguished by their different $\mathrm{H}_{2} \mathrm{~S} / \mathrm{SO}_{2}$ ratios. Localities indicated by letters as in Fig. 2.

emissions ( 0.5 to $3.5 \mathrm{~mol} \%$ ). Although high $\mathrm{H}_{2}$ contents are recognized in gases of active magmas (Gerlach and Nordlie, 1975; Gerlach, 1980, 1993b; Symonds and Reed, 1993), the contents are not nearly as high as observed in some of our samples. The $\mathrm{H}_{2}$ contents in fluid inclusions may be the result of: (a) postdepositional reactions in the fluid inclusions; (b) selective trapping during the formation of very small fluid inclusions; (c) reaction of water with ferrous iron in the magma $\left(2 \mathrm{FeO}+\mathrm{H}_{2} \mathrm{O}=\mathrm{Fe}_{2} \mathrm{O}_{3}+\mathrm{H}_{2}\right)$; (d) dissociation of water (e.g., $\mathrm{H}_{2} \mathrm{O}=\mathrm{H}_{2}+1 / 2 \mathrm{O}_{2}$ ) or other reactions (e.g., $\mathrm{SO}_{2}+2 \mathrm{H}_{2} \mathrm{O}=\mathrm{H}_{2} \mathrm{SO}_{4}+\mathrm{H}_{2}$ ) during and (or) after separation of a fluid from the magma; or (e) the addition of $\mathrm{H}_{2}$ that separated from deeper magmatic fluids.

The fluid inclusions lack the possible reactionproduct gas species necessary to generate the measured $\mathrm{H}_{2}$ contents. Furthermore, it is not likely that the high $\mathrm{H}_{2}$ content of alunite inclusion fluids resulted from the selective trapping in small fluid inclusions. The mechanics of gas trapping have been examined in individual synthetic fluid inclusions in quartz (Landis, unpublished data). In these studies, rapidly sealed (quenched) fluids in small inclusions $(<5 \mu \mathrm{m}$ diameter) commonly are not in equilibrium with the parental fluid at the growth surface of the precipitating mineral. That is, on a scale of several micrometers, large chemical gradients form in the fluid at the fluidcrystal interface, and the composition of the fluids trapped in very small fluid inclusions therefore differs from that of the parental fluid. Disequilibrium gas compositions can therefore occur in very small inclusions. The results for synthetic fluid inclusions in quartz suggest that, if the precipitation of alunite involved reactions that released $\mathrm{H}_{2}$, e.g.,

$$
\begin{aligned}
& \mathrm{KCl}+3 \mathrm{AlCl}_{3}+2 \mathrm{H}_{2} \mathrm{SO}_{4}+6 \mathrm{H}_{2} \mathrm{O} \\
& \quad=\mathrm{KAl}_{3}\left(\mathrm{SO}_{4}\right)_{2}(\mathrm{OH})_{6}+5 \mathrm{Cl}_{2}+5 \mathrm{H}_{2}
\end{aligned}
$$

then $\mathrm{H}_{2}$ could be trapped in disequilibrium amounts in submicrometer fluid inclusions during depositional growth of alunite. Alunite source fluids appear generally to be of low density but of highly variable water content. Disequilibrium trapping of $\mathrm{H}_{2}$ by this reaction would be more effective in a high-density aqueous fluid, and if this or similar reactions were the dominant source of $\mathrm{H}_{2}$, a positive correlation between $\mathrm{H}_{2} \mathrm{O}$ and $\mathrm{H}_{2}$ in fluids released from small inclusions would be expected (not stoichiometric). Fig. 12 shows

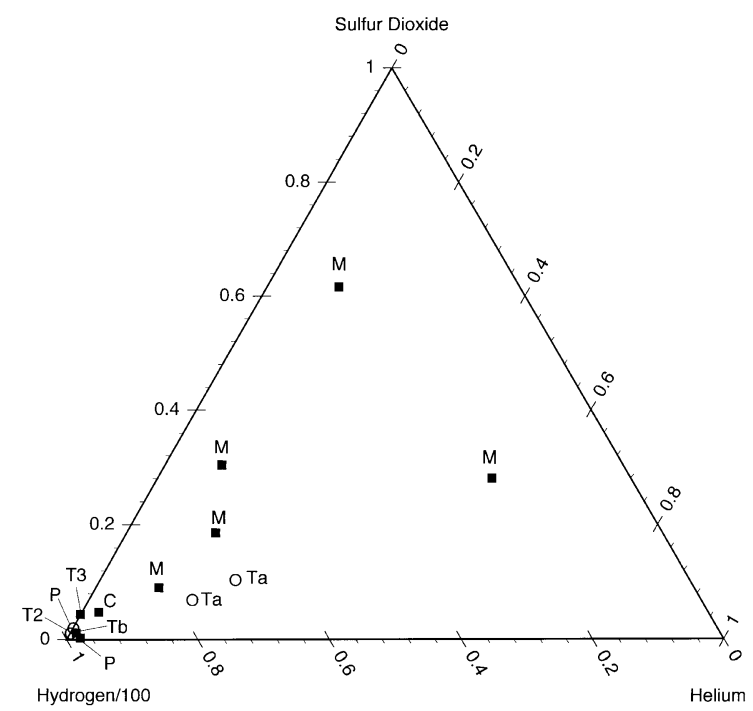

Fig. 11. Plot of $\mathrm{H}_{2}-\mathrm{SO}_{2}-\mathrm{He}$ relative abundances in magmatic-steam and magmatic-hydrothermal fluids. Magmatic-steam fluids are strongly characterized by the abundance of these three gas species. The magmatic-steam end-member fluids from Marysvale alunite are the most enriched in $\mathrm{SO}_{2}$ and $\mathrm{He}$, whereas $\mathrm{H}_{2}$ is generally equally abundant both in magmatic-steam and magmatic-hydrothermal environments. 


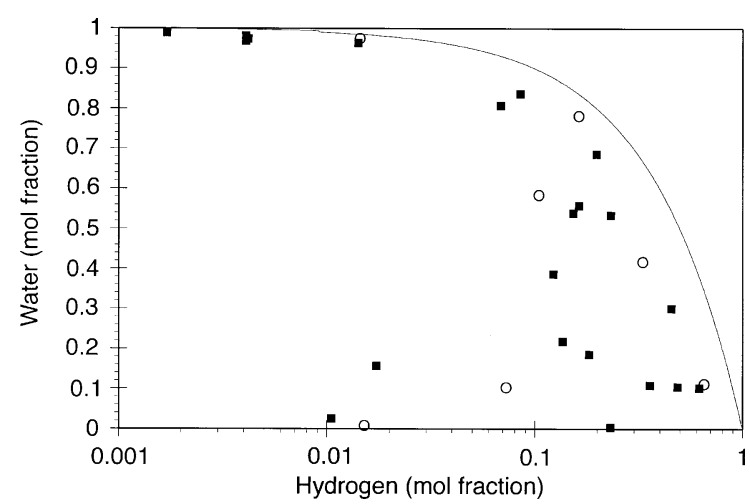

Fig. 12. Plot of $\mathrm{H}_{2} \mathrm{O}-\mathrm{H}_{2}$ contents in mole fraction of magmatichydrothermal and magmatic-steam fluids. Hydrogen concentrations increase with decreasing water content, indicating that $\mathrm{H}_{2}$ abundances are not an artifact of compositions attained at the fluidinclusion interface, but were actually present in the fluid as it was trapped (see text). Both crush- and thermal-release fluid compositions are plotted. Magmatic-steam fluids ( $\boldsymbol{\square})$; magmatic-hydrothermal fluids (O). The $X_{\mathrm{H}_{2} \mathrm{O}}=X_{\mathrm{H}_{2}}$ mixing line is shown for reference, and $X_{\mathrm{H}_{2}}$ is plotted in $\log$ units to expand the scale.

$X_{\mathrm{H}_{2} \mathrm{O}}$ versus $X_{\mathrm{H}_{2}}$ of the alunite fluids, with an $\mathrm{H}_{2} \mathrm{O}-\mathrm{H}_{2}$ mixing line for reference. The $\mathrm{H}_{2} \mathrm{O}$ content of the fluids exhibits an inverse linear correlation with that of $\mathrm{H}_{2}$. The importance of chloride and fluoride complexes to vapor transport of chemical components necessary to alunite formation from a low-density fluid is unknown, but $\mathrm{H}_{2}$ contents do not correlate with that of $\mathrm{HCl}$ or $\mathrm{HF}$ derived from important ligands such as $\mathrm{KCl}$ or $\left(\mathrm{AlF}_{3}\right)_{2}-\mathrm{AlF}_{2} \mathrm{O}$ (cf. Symonds et al., 1992). The high $\mathrm{H}_{2}$ contents in alunite fluid inclusions are therefore concluded to reflect predominantly those of the primary hydrothermal fluids rather than depositional interface effects.

The high $\mathrm{H}_{2}$ contents of magmatic fluids were likely created initially from the breakdown of $\mathrm{H}_{2} \mathrm{O}$ in the magma as it reacted with ferrous iron (Sato, 1978), and the creation of $\mathrm{H}_{2}$ probably started while the magma was at great depths and may have continued during the rise of these fluids to higher levels even after they left the magma. Hydrogen is the most mobile of magmatic gases, and it is not hard to imagine that it would escape from a magma at a greater rate than water and other volatiles (cf. Sato and Wright, 1966). The high $\mathrm{H}_{2}$ contents are recognizable in the alunite inclusion fluids because they have "sampled" the magmatic volatiles much closer to their magma source than is possible by sampling volcanic volatiles at the surface by traditional methods. The underlying magmatic fluids may have contributed to further enrichment of the $\mathrm{H}_{2}$ contents of alunite inclusion fluids, as proposed in Section 6.7.

\subsection{Equilibrium speciation and $\mathrm{fO}_{2}$ of magmatic- steam and magmatic-hydrothermal fluids}

The data for the gas of thermally and crushreleased magmatic-steam and magmatic-hydrothermal alunite inclusion fluids are representative of the composition of the parental fluids, with possible modifications by retrograde reactions of gas species since their entrapment within the fluid inclusions. The SOLVGAS computer program and thermochemical database (Symonds and Reed, 1993) were used to compute gas equilibria by solving simultaneously a set of mass-balance and mass-action equations written for all gas species in the alunite fluid-inclusion data for each sample. The thermodynamic equilibrium gasspeciation calculations over a range of temperature $\left(100-1200{ }^{\circ} \mathrm{C}\right)$ and pressure $\left(100\right.$ to $\left.1 \times 10^{5} \mathrm{kPa}\right)$ did not predict the elevated $\mathrm{H}_{2}$ contents observed in our samples and did not predict the observed $\mathrm{SO}_{2}, \mathrm{CO}$, and $\mathrm{CH}_{4}$ concentrations.

The data in Table 1 were recast into thermochemical components as input to SOLVGAS. A search was made for convergence of correspondence temperatures, or CT, for the gas mixture of each sample (Symonds et al., 1994). CT is the temperature (at a selected pressure) at which the logarithm of calculated/measured mole fraction of a species equals zero (i.e., $\log \left(X_{\text {Calc }} / X_{\text {Meas }}\right) \approx 0$, or $X_{\text {Calc }} / X_{\text {Meas }} \approx 1$ ). Equilibrium convergence is determined when the CTs of all considered gas species mutually approach zero. A practical limit of $\pm 10 \%$ equilibrium CT divergence (Symonds et al., 1994) was used; failure to converge implies a disequilibrium gas mixture. Multiple CTconvergence partial equilibrium conditions were achieved with the calculations, and efforts to correct measured input compositions for hypothetical causes of disequilibrium (Gerlach and Casadevall, 1986; Symonds et al., 1994) did not improve the partial equilibrium results. The alunite fluid-inclusion data do not represent equilibrium gas mixtures, but rather partial equilibrium (cf. Barton, 1963); that is, some gas species appear to approach equilibrium as indicated by agreement between calculated and 
measured gas/species concentration at the same CT, but others do not.

The $\log \left(X_{\text {Calc }} / X_{\text {Meas }}\right)$ results of SOLVGAS analyses are plotted against temperature in Fig. 13. Deposition of most magmatic-steam and magmaticmatic-hydrothermal alunite is thought to occur at less than $1 \mathrm{~km}$ or $10 \mathrm{mPa}$ (e.g., Hedenquist and Lowenstern, 1994; Bethke et al., this Volume). Because fluid pressure does not have a large effect on the calculated results and is only important for gas species coupled by reactions with large $\Delta V$, the effect of pressure on the calculations is not presented here. Equilibrium gas speciation changes dramatically with temperature. Approximate CTs, and a partial gas/ species high- and low-temperature CT, are illustrated
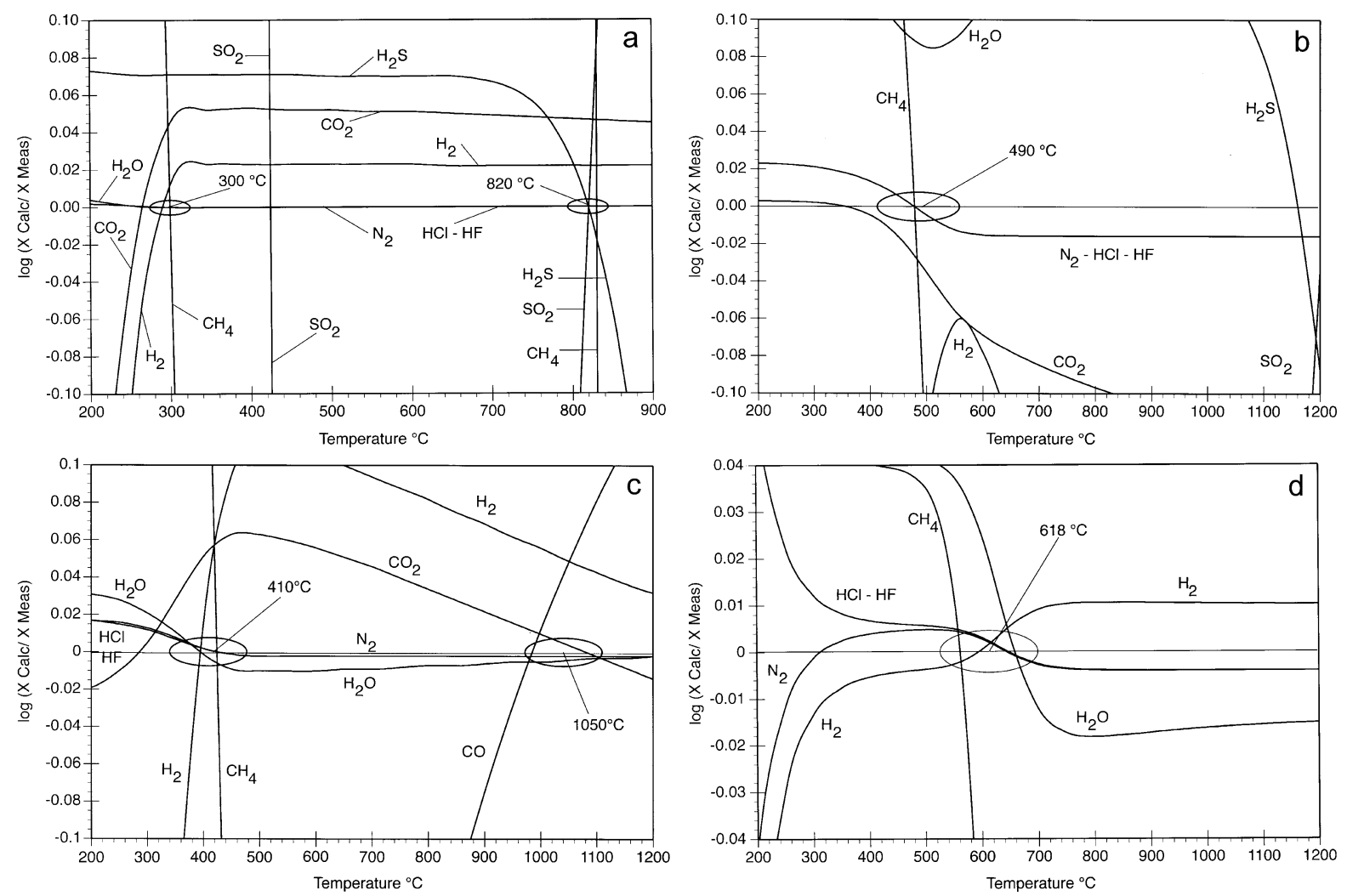

Fig. 13. Plot of example results from SOLVGAS thermodynamic equilibrium calculations. Equilibrium gas speciation was calculated from the starting alunite fluid-inclusion gas compositions in Table 1, at various temperatures. A Correspondence Temperature (CT) is obtained at the point where the $\log \left(X i_{\text {Calc }} / X i_{\text {Meas }}\right)$ is within approximately $10 \%$ for each major gas species. $X i$ is the calculated and measured mole fractions of species ' $i$ '. Evaluation of measured gas compositions indicates disequilibrium to partial thermodynamic equilibrium, and at a log $f \mathrm{O}_{2}$ that is well below predicted conditions based upon mineral assemblages (hematite+alunite) and $\log f \mathrm{O}_{2}$ buffers (NNO-MH-QFM). (a) Magmatichydrothermal Tambo T01a: partial equilibrium at approximately $300{ }^{\circ} \mathrm{C}$ for $\mathrm{H}_{2}-\mathrm{H}_{2} \mathrm{O}-\mathrm{CO}_{2}-\mathrm{CH}_{4}$, and at $820{ }^{\circ} \mathrm{C}$ for $\mathrm{CO}_{2}-\mathrm{CH}_{4}-\mathrm{SO}_{2}-\mathrm{H}_{2} \mathrm{~S}$. (b) Magmatic-hydrothermal Tapajós 1: poor convergence of $C T \mathrm{~s}$ at about $490{ }^{\circ} \mathrm{C}$. (c) Magmatic-steam Marysvale M341b: partial CT equilibrium at 410 and at $1050{ }^{\circ} \mathrm{C}$. (d) Magmatic-steam Marysvale M939a4: CT convergence equilibrium temperature of $618{ }^{\circ} \mathrm{C}$. 
species input for each calculation. The calculated log $\mathrm{fO}_{2}$ versus temperature for each thermally released gas is plotted in Fig. 14. Also plotted is the estimated $\log f \mathrm{O}_{2}$ (Luhr and Melson, 1996; Evans and Scaillet, 1997) of the anhydrite-bearing dacitic magma that erupted in 1991 from Mount Pinatubo, Philippines $\left(\mathrm{NNO}+1.7\right.$, at $780{ }^{\circ} \mathrm{C}$ and $220 \mathrm{mPa}$ ), and released about $18 \times 10^{6}$ tonnes of $\mathrm{SO}_{2}$.

The sulfur-gas redox speciation of magmatic-steam and magmatic-hydrothermal fluids reflects the fundamentally different nature of fluid processes in the two environments. Fluids released from deep I-type magmas have oxidation states along the QFM and NNO buffers, resulting in $\mathrm{H}_{2} \mathrm{~S}$-rich to $\mathrm{SO}_{2}$-rich fluids (Gerlach, 1986, 1993b; Giggenbach, 1987; Hedenquist, 1995). However, fluid reactions with wallrocks below the brittle-ductile transition typically result in $\mathrm{H}_{2} \mathrm{~S}$-rich fluids at higher levels in the crust (Ohmoto and Rye, 1979; Rye, this Volume). Magmatic fluids (such as those at Marysvale) released from shallow high-temperature magmas are more likely to be $\mathrm{SO}_{2}$ rich (Symonds et al., 1990, 1994; Snyder et al., 2001). Even deep magmas can have $\mathrm{SO}_{2}$-rich fluids because increasing the $f \mathrm{O}_{2}$ from $\mathrm{QFM}$ to $\mathrm{QFM}+2\left(=\log f \mathrm{O}_{2}\right.$ of $\mathrm{QFM}+2 \log$ units) also increases, from $\sim 5 \%$ to $>80 \%$, the proportion of sulfur dissolved as sulfate in the melt (Carroll and Rutherford, 1988; Carroll and Webster, 1994). Sulfur dioxide becomes the dominant sulfur species in the fluid at $\log f \mathrm{O}_{2} \geq \mathrm{QFM}-1$ (O'Neill, 1987), such as observed for the 1991 eruptions of Mount Pinatubo. The $\mathrm{H}_{2} \mathrm{~S}_{/} \mathrm{SO}_{4}^{2-}$ of higher level fluids is controlled by equilibrium with rocks below the brittleductile transition at about $400{ }^{\circ} \mathrm{C}$ in the magmatichydrothermal environment. The $\mathrm{H}_{2} \mathrm{~S}_{/} \mathrm{SO}_{4}^{2-}$ of magmatic-hydrothermal fluids may move away from control by rock buffers above the brittle-ductile

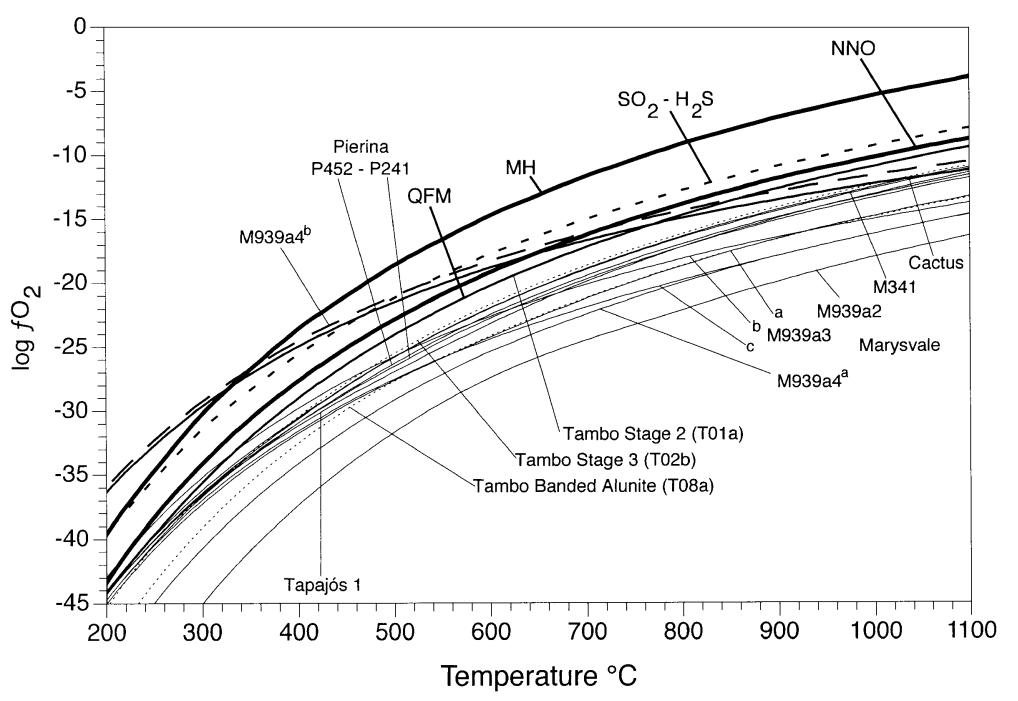

Fig. 14. Plot of $\log f \mathrm{O}_{2}$ versus temperature, showing the oxygen fugacity predicted from SOLVGAS calculations based on gas compositions obtained in this study as described in Fig. 13. HM=hematit-magnetite buffer (calculated from Chase, 1998), NNO=nickel-nickel oxide buffer (Luhr and Melson, 1996; Evans and Scaillet, 1997; Huebner and Sato, 1970), $\mathrm{SO}_{2}-\mathrm{H}_{2} \mathrm{~S}$ isomolar univariant (calculated from SOLVGAS and NIST-JANAF data; Symonds and Reed, 1993; Chase, 1998), and QFM=quartz-fayalite-magnetite buffer (NIST-JANAF, Chase, 1998; O'Neill, 1987). All $\log f \mathrm{O}_{2}$ curves fall at or below the $\mathrm{QFM} f \mathrm{O}_{2}$ buffer over the entire range of temperature at $100 \mathrm{kPa}$. The analyzed gas compositions recast to thermodynamic equilibrium are not compatible with observed mineral assemblages or other volcanic gas data. At $100 \mathrm{mPa}$, the curve for Marysvale M939a $4^{\mathrm{b}}$ fluid crosses the HM buffer into the hematite-stable region. In this calculation, the composition was adjusted by taking the total $\mathrm{H}_{2}$ content of the fluids and recasting it to $0.5 \% \mathrm{H}_{2}, 3.5 \% \mathrm{SO}_{2}$ and remainder $\mathrm{H}_{2} \mathrm{O}$ (solid line), and to $0.5 \% \mathrm{H}_{2}$ with remainder $\mathrm{SO}_{2}$ (dashed line). Marysvale fluid composition M939a3 adjusted to (a) $100 \mathrm{kPa}$, (b) $100 \mathrm{mPa}$, and (c) $100 \mathrm{kPa}$ and $\mathrm{H}_{2}$ recalculated to $0.5 \%$ with the remainder as $\mathrm{H}_{2} \mathrm{O}$. The lowest $\log f \mathrm{O}_{2}$ curve is for Marysvale M939a2, which has a very unusual content of $94 \% \mathrm{CO}$. The abundance of reduced-species $\mathrm{H}_{2}$ and $\mathrm{CO}$ depresses the Marysvale fluid $\log f \mathrm{O}_{2}$ curves (Table 1). The fluids in the Tambo sequence of three samples correlate with an increase in $\mathrm{H}_{2}$ from 1.44\% (magmatic-hydrothermal: Stage 2) to 6.68\% (magmatic-steam: Stage 3) to 45.38\% (magmatic-steam: Banded alunite). Tambo fluids show an increase in $\mathrm{H}_{2}$ and $\mathrm{SO}_{2}$, with a decrease in $\mathrm{H}_{2} \mathrm{~S}$ with successive alunite deposition events. Pierina $\log f \mathrm{O}_{2}$ magmatic-steam and magmatic-hydrothermal curves are not significantly different. 
transition, during the period when $\mathrm{SO}_{2}$ disproportionates and $\mathrm{HSO}_{4}^{-}$is formed in a condensing vapor plume, and when the Fe in the rock is removed by reaction with $\mathrm{H}_{2} \mathrm{~S}$ to produce pyrite.

The calculated $\log f \mathrm{O}_{2}$ for all magmatic-steam and magmatic-hydrothermal fluids as a function of temperature (Fig. 14) ranges from the QFM buffer (Tambo Stage 2) to about QFM-7.5 (Marysvale M939a2). Marysvale magmatic-steam fluids are among the most reducing, and the $\log f \mathrm{O}_{2}$ values of other magmatic-steam fluids completely overlap those for magmatic-hydrothermal fluids. Marysvale fluids yield a calculated $\log f \mathrm{O}_{2}$ of about -24 to -27.2 at the approximate $610{ }^{\circ} \mathrm{C} \mathrm{CT}$, and Pierina magmaticsteam and magmatic-hydrothermal fluids yield a $\log$ $f \mathrm{O}_{2}$ of about -24.8 . At 200 to $350{ }^{\circ} \mathrm{C}$, the $\log f \mathrm{O}_{2}$ of all alunite inclusion fluids $\left(-41<\log f \mathrm{O}_{2}<-33\right)$ are below the hematite+alunite stablility field (Crerar and Barnes, 1976; Stoffregen, 1987; Deyell, 2002). The calculated $\log f \mathrm{O}_{2}$ values of both magmatic-steam and magmatic-hydrothermal alunite inclusion fluids are much too low for parental fluids, as indicated by the mineral assemblage alunite+hematite.

\subsection{Summary of redox conditions of magmatic-steam and magmatic-hydrothermal fluids}

Of all of the magmatic-steam inclusion fluids analyzed, those from Marysvale seem to be the most closely linked directly to magma. Compared to Marysvale, the magmatic-steam fluids from Pierina and Tambo have higher $\mathrm{H}_{2} \mathrm{O}$ and $\mathrm{H}_{2} \mathrm{~S}$, and lower $\mathrm{H}_{2}$ contents, that are consistent with less-rapid ascent of fluids after exsolution from the magma. Slower rates of fluid ascent allow for greater diffusive separation of $\mathrm{H}_{2}$, greater condensation of $\mathrm{H}_{2} \mathrm{O}$, greater $\mathrm{H}_{2} \mathrm{~S}$ production from the disproportionation of $\mathrm{SO}_{2}$, and more isotopic equilibration among aqueous sulfur species in the fluids (Rye, this Volume; Fifarek and Rye, this Volume).

In contrast, magmatic-hydrothermal alunite inclusion fluids that are derived from below the brittleductile transition at about $400{ }^{\circ} \mathrm{C}$ are initially $\mathrm{H}_{2} \mathrm{~S}$ dominant (Symonds and Reed, 1993; Rye, 1993) because the ratio of their reduced to oxidized sulfur species is buffered by wallrocks. Later, at higher levels, these fluids may become $\mathrm{SO}_{4}^{2-}$-dominant as $\mathrm{SO}_{2}$ in a condensing vapor plume disproportionates to produce sulfuric acid and overwhelms the rock buffer. The amount of $\mathrm{H}_{2}$ observed in the alunite magmatichydrothermal inclusion fluids is also in excess of the equilibrium $f \mathrm{O}_{2}$ values controlled by either rock or fluid buffers. Below about $400{ }^{\circ} \mathrm{C}, \mathrm{SO}_{2}$ in a condensing magmatic vapor fluid disproportionates to $\mathrm{H}_{2} \mathrm{SO}_{4}$ and $\mathrm{H}_{2} \mathrm{~S}$ (Holland, 1965; Rye et al., 1992):

$4 \mathrm{SO}_{2}+4 \mathrm{H}_{2} \mathrm{O}=3 \mathrm{H}_{2} \mathrm{SO}_{4}+\mathrm{H}_{2} \mathrm{~S}$

The $\mathrm{H}_{2} \mathrm{~S}$ reacts with $\mathrm{Fe}$ in the rocks to produce pyrite, and the $\mathrm{H}_{2} \mathrm{SO}_{4}$ leads to the formation of alunite. The high $\mathrm{H}_{2}$ content observed in the inclusion fluids suggests that reduction of $\mathrm{SO}_{2}$ may also occur in the magmatic-hydrothermal environment by (i) reaction with the disequilibrium amounts of $\mathrm{H}_{2}$ in the fluids

$\mathrm{SO}_{2}+3 \mathrm{H}_{2}=\mathrm{H}_{2} \mathrm{~S}+2 \mathrm{H}_{2} \mathrm{O}$

or (ii) by coupled reaction with $\mathrm{Fe}$ in the host rock

$\mathrm{SO}_{2}+2 \mathrm{H}_{2}+2 \mathrm{Fe}_{3} \mathrm{O}_{4}=\mathrm{H}_{2} \mathrm{~S}+\mathrm{H}_{2} \mathrm{O}+3 \mathrm{Fe}_{2} \mathrm{O}_{3}$

Possible reaction (4), however, must be of limited extent because portions of the host rock in many highsulfidation hydrothermal alunite occurrences are so thoroughly altered that nothing remains but vuggy silica. The low $f \mathrm{O}_{2}$ observed in both the magmaticsteam and magmatic-hydrothermal alunite inclusion fluids clearly needs further investigation.

\subsection{Gas solubility in magmas, and mantle and crustal gas sources}

The incorporation of gas species into a fluid that separates from an ascending magma will be accompanied by chemical partitioning and fractionation as described by the gas-specific Henry's Law constants (reviewed by Carroll and Holloway, 1994). Giggenbach $(1996,1997)$ has shown that a fluid phase will start to separate from a cooling and ascending magma at depths of $\sim 60 \mathrm{~km}$, near that of arc magma generation. At this depth, nearly $90 \%$ of the $\mathrm{H}_{2} \mathrm{O}$ will remain in the melt, but the $\mathrm{H}_{2} \mathrm{O}$ content will decrease with crystallization and declining pressure until most is released by the time the melt is near $1 \mathrm{~km}$ of the surface. However, $>90 \%$ of the $\mathrm{He}, \mathrm{Ne}$, and $\mathrm{CO}_{2}$ will be exsolved from the melt into the fluid phase by the time the magma reaches depths of 20 $\mathrm{km}$. The solubility of noble gases in silicate melts has received extensive attention (e.g., Carroll and Web- 
ster, 1994; Shibata et al., 1998; Ozima and Podosek, 2002). It can be concluded from these investigations on molecular gas solubility in magmas that $\mathrm{He}$ and $\mathrm{Ne}$ in the alunite inclusion fluids must have exsolved into a supercritical phase at great depths while most of the $\mathrm{H}_{2} \mathrm{O}$ remained in the ascending parental magma. Until reaching shallow depths in the upper crust where fluids become subcritical and phase separations occur as fluids cross the brittle-ductle transition into fractured rock, both magma and separated fluid remain intimately intermixed. The fluid remains an open system, with input of fluids both exsolved from the magma and from surrounding crust.

The $1.87 \mathrm{Ga}$ Tapajós magmatic-hydrothermal fluids in alunite contain $\mathrm{He}$ with an $\mathrm{R} / \mathrm{Ra}$ of 19.5 , which is much higher than the ratio in the younger magmatic-steam and magmatic-hydrothermal fluids (0.02 to 0.27$)$. None of these fluids contains significant Atm or ASW gases, and our data suggest that the $\mathrm{He}$ in the magmatic-steam and magmatic-hydrothermal fluids is largely crustal-derived, but the $\mathrm{Ne}$ is largely mantle-derived. This apparent contradiction of crustal and mantle sources for these gases is easily explained by the model developed by Fournier (1999) wherein supercritical fluids exsolve at depth and ascend as a separate phase with their parental magma. The low $\mathrm{R} / \mathrm{Ra}$ of $\sim 0.02$ for $\mathrm{He}$ indicates that it and other magmatic volatiles migrated in a separate vapor phase that entrained crustal He from the surrounding rocks as the vapor phase ascended through the crust. Helium, because of its greater diffusive mobility, is released selectively from radiogenic and nucleogenic sites within the crust and is readily incorporated into the supercritical fluid coexisting with rising magma, largely masking any original mantle He-isotope signature in the magma. Rock permeabilities in the mid- to lower-crust readily support fluid-solute transport over large rock volumes (Manning and Ingebritsen, 1999). However, Ne is more tightly bound in minerals in the crust and, consequently, is not added in sufficient quantities to mask the original mantle Neisotope signature of the magma.

\subsection{Magmatic-steam and magmatic-hydrothermal model for alunite}

Significant differences as well as similarities are apparent in the gas chemistry of magmatic-steam and magmatic-hydrothermal alunite inclusion fluids. More research is needed to understand better the importance of the high $\mathrm{H}_{2}$ contents in magmatic-steam and magmatic-hydrothermal fluids, and the importance of disequilibrium gas speciation in which the required calculated $\log f \mathrm{O}_{2}$ values of the parental fluids are not compatible with the stability of the host alunite and associated hematite. A conceptual chemical model of magmatic-steam and magmatic-hydrothermal fluid evolution is illustrated in Fig. 15. The calculated log $f \mathrm{O}_{2}$-temperature relations from SOLVGAS are summarized in a band that is plotted as individual curves in Fig. 14. The starting point is composition A which represents the compositions of magmatic volatiles at approximately the conditions of partial equilibrium identified by SOLVGAS, but at realistic $\mathrm{SO}_{2} / \mathrm{H}_{2} \mathrm{~S}$ ratios near the isomolar $\left(\mathrm{SO}_{2} / \mathrm{H}_{2} \mathrm{~S}=1\right)$ curve as calculated by Ohmoto (1986).

Magmatic-steam fluids of composition A in Fig. 15 rapidly rise from a magma into open fractures above the brittle-ductile transition along a trajectory that crosses the magnetite-hematite buffer into the stability field labeled 'MS Alunite'. This trajectory is the most likely one for the parental fluids of Marysvale magmatic-steam alunite. Alternatively, composition A fluids could also rise slowly so that they react with wallrocks to composition $\mathrm{B}$, and then rapidly ascend across the brittle-ductile transition along a different trajectory into the field of magmatic-steam alunite. This would be a possible path for the parental fluids of the Pierina magmatic-steam alunite. Magmatic-hydrothermal alunite parental fluids equilibrate with crustal rocks below the brittle-ductile transition prior to their ascent to shallow levels (Rye, this Volume; Bethke et al., this Volume). As vapor-phase fluids rise from the brittle-ductile transition and condense in open fractures, where $\mathrm{SO}_{2}$ disproportionates to form $\mathrm{SO}_{4}^{2-}$ and leads to the formation of magmatic-hydrothermal alunite, the residual liquids below the brittle-ductile transition lose most of their volatiles, especially $\mathrm{He}$, and undergo a decrease in $\mathrm{N}_{2} /$ Ar. Such a liquid-phase fluid might be positioned at composition C. Volatiles such as $\mathrm{H}_{2}$ from the underlying magma may continue to be added to the magmatic-hydrothermal liquid fluids, or a pulse of $\mathrm{H}_{2}$-rich fluids from the magma may mix with magmatic-hydrothermal vapor-phase fluids at higher levels. The resulting fluids would be $\mathrm{H}_{2} \mathrm{~S}$ - and $\mathrm{CO}_{2}$-dominant, high in $\mathrm{H}_{2}$ devoid of $\mathrm{He}$, and 


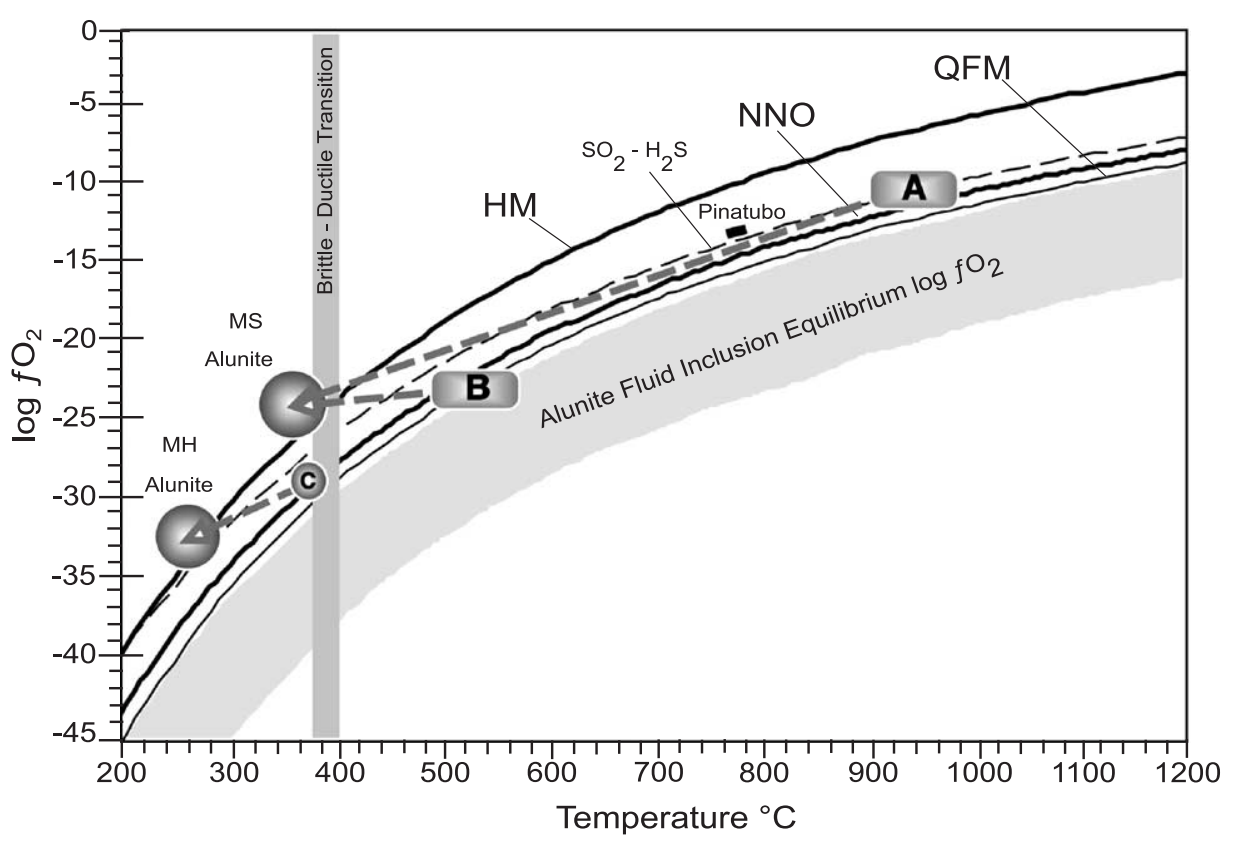

Fig. 15. Plot of $\log f \mathrm{O}_{2}$ versus temperature, illustrating an evolution model for deposition of magmatic-steam and magmatic-hydrothermal alunite that is consistent with the gas chemistry of alunite fluid inclusions. The $f \mathrm{O}_{2}$ buffers are as defined in Fig. 14 , and calculated log $f \mathrm{O}_{2}$ of magmatic-steam and magmatic-hydrothermal alunite inclusion fluids are defined within the labeled gray region. Data for the 1991 dacite eruption of Mount Pinatubo (Luhr and Melson, 1996; Evans and Scaillet, 1997) are plotted to indicate strongly $\mathrm{SO}_{2}$-dominant magmatic gas conditions. Vertical rectangle is diagrammatic and shows the approximate temperature of the brittle-ductile transition. The circles show the modeled composition of magmatic-hydrothermal and magmatic-steam fluids based on the data in this study. The presumed starting $f \mathrm{O}_{2}$ of magmatic-steam fluids immediately after exsolution from a magma is shown by A; B shows the presumed $f \mathrm{O}_{2}$ of evolved magmatic fluids after ascent to just below the brittle-ductile transition and equilibration with crystalline rocks. Compositions $\mathrm{A}$ and $\mathrm{B}$ are representative of possible magmatic-steam fluids if pressure release is rapid. $\mathrm{C}$ is a possible composition of magmatic-hydrothermal fluids that may receive contributions of reduced gases from underlying fluids during the rise of a vapor phase above the brittle-ductile transition. The starting conditions of magmatic gas were approximated from magmatic-steam and magmatic-hydrothermal fluid partial equilibrium SOLVGAS-calculated correspondence temperatures and $f \mathrm{O}_{2}$, and from other constraints derived from geological and mineralogical conditions and gas data.

would yield the low calculated (disequilibrium) log $f \mathrm{O}_{2}$ observed for the magmatic-hydrothermal fluids.

\section{Conclusions}

This study is the first attempt to analyze the gas components of the small fluid inclusions in crystals of magmatic-hydrothermal and magmatic-steam alunite. Although this investigation is a reconnaissance, and some of the discussion that it engenders is speculative, the consistency of the results for magmatic-hydrothermal and magmatic-steam alunite inclusion fluids is remarkable. The results not only support existing models for alunite formation (Rye, this Volume) but also are consistent with the geological and isotopic variations observed for magmatic-hydrothermal and magmatic-steam alunite at different deposits (cf. Fifarek and Rye, this Volume; Deyell et al., this Volume; Bethke et al., this Volume). Such consistency supports the conclusions of Landis et al. (this Volume) that alunite-hosted fluid inclusions retain their primary fluid compositions. These compositions can provide important clues both to the environments and mechanisms of alunite formation and to the general chemical composition and source(s) of magmatic volatiles. Further detailed studies of alunite inclusion fluids in individual deposits are merited.

The discovery of large, disequilibrium amounts of $\mathrm{H}_{2}$ in all of the alunite inclusion fluids is problematic and requires further study. However, it is important to note that the analyzed alunite samples have incorporated magmatic gases much closer to their sources than has been possible from any surface sampling of 
magmatic gases. Generalized conclusions that can be made are:

(1) Other than for large disequilibrium amounts of reduced gases, alunite fluid inclusions preserve magmatic volatile compositions that are broadly similar to those derived from thermodynamic equilibrium speciation models (Symonds and Reed, 1993) based on reported compositions for volcanic gases (Gerlach and Nordlie, 1975; Giggenbach and Le Guern, 1976; Gerlach, 1993a; Giggenbach, 1997).

(2) The relative abundance of gas species for magmatic-steam fluids is $\mathrm{H}_{2} \mathrm{O}>\mathrm{H}_{2}>\mathrm{N}_{2}>\mathrm{CO} \gg$ $\mathrm{CO}_{2}>\mathrm{Ar}>\mathrm{CH}_{4} \gg \mathrm{O}_{2}>\mathrm{HF}>\mathrm{SO}_{2}>\mathrm{He}>\mathrm{HCl}>\mathrm{H}_{2} \mathrm{~S}$, and for magmatic-hydrothermal fluids the relative abundance is $\mathrm{H}_{2} \mathrm{O} \gg \mathrm{H}_{2}>\mathrm{CO}_{2} \gg \mathrm{N}_{2}>\mathrm{HF} \gg$ $\mathrm{CH}_{4}>\mathrm{Ar}>\mathrm{CO}>\mathrm{O}_{2}>\mathrm{HCl}>\mathrm{H}_{2} \mathrm{~S}>\mathrm{SO}_{2}$. Magmaticsteam alunite forms from low-density $\mathrm{SO}_{2}$-dominant fluids, whereas magmatic-hydrothermal alunite forms from higher density $\mathrm{H}_{2} \mathrm{~S}$-dominant fluids.

(3) The data show no evidence that atmospheric gas or air-saturated water (meteoric water) was involved in either the magmatic-steam or magmatic-hydrothermal fluids. Oxidation of $\mathrm{SO}_{2}$ to aqueous sulfate in magmatic-steam fluids was not accomplished by entrained atmospheric oxygen.

(4) Sulfur dioxide dominates magmatic-steam fluids; concentrations are as high as $4088 \mathrm{ppmV}$ and have an average $\mathrm{SO}_{2} / \mathrm{H}_{2} \mathrm{~S}$ of 202. Magmatichydrothermal fluids are more $\mathrm{H}_{2} \mathrm{~S}$-rich, with an average $\mathrm{SO}_{2} / \mathrm{H}_{2} \mathrm{~S}$ of 0.7 . These results are consistent with the derivation of magmatic-steam fluids directly from a magma at shallow depth, and with magmatic-hydrothermal fluid derivation largely from condensed evolved magmatic fluids that accumulated near the top of the magma chamber below the brittle-ductile transition.

(5) Multiple partial equilibrium reactions among different gas species (e.g., $\mathrm{H}_{2} \mathrm{O}-\mathrm{H}_{2}, \mathrm{SO}_{2}-\mathrm{H}_{2} \mathrm{~S}$, $\left.\mathrm{CO}_{2}-\mathrm{CH}_{4}\right)$ at different $P-T$ conditions are preserved in the gas mixtures. The data for neither the magmatic-hydrothermal nor the magmaticsteam alunite fluid-inclusion gas are representative of equilibrium gas mixtures. These fluids were in disequilibrium when they were trapped in the inclusions. These results are not surprising for magmatic-steam fluids, given their presumed rapid ascent, but somewhat similar results for magmatic-hydrothermal fluids are surprising.

(6) The extraordinary high concentrations of $\mathrm{H}_{2}$ gas that characterize both magmatic-steam and magmatic-hydrothermal alunite inclusion fluids are enigmatic. The $\mathrm{H}_{2}$ is believed to be largely derived from the reaction of water with ferrous iron in the magma. The accumulation of $\mathrm{H}_{2}$ in disequilibrium amounts in the hydrothermal fluids is believed to be related to its high mobility relative to other components of magmatic fluids. The $\mathrm{H}_{2}$ contents in magmatic-steam alunite parental fluids are probably derived directly from a magma. The high $\mathrm{H}_{2}$ contents of the magmatic-hydrothermal alunite parental fluids may have resulted from the 'feeding' of additional magmatic volatiles to the low-density magmatic-hydrothermal fluids at higher levels.

(7) The He isotopic data indicate a crustal source for $\mathrm{He}$, whereas the $\mathrm{Ne}$ isotopic data indicate a large mantle component for $\mathrm{Ne}$ in the alunite inclusion fluids. This difference suggests that these and probably other magmatic gas species separated as a fluid phase from the silicate melt at considerable depth in the crust, and that the fluid phase incorporated additional gases from crustal sources as it ascended with the melt.

\section{Acknowledgements}

We thank Cari Deyell, Rich Fifarek, Skip Cunningham, and Caetano Juliani for providing the welldocumented samples for this work. Discussions with Mark Reed and Phil Bethke were extremely valuable, as were reviews by Paul Barton, Phil Bethke, and Bob Seal. [PD]

\section{References}

Ballentine, C.J., Barford, D.N., 2000. The origin of air-like noble gas in MORB and OIB. Earth Planet. Sci. Lett. 180, 39-48.

Barton Jr., P.B., 1963. Equilibrium in ore deposits. Spec. Pap.Miner. Soc. Am. 1, 171-185.

Bethke, P.M., Rye, R.O., Stoffregen, R.E., Vikre, P., 2005. Evolution of the magmatic-hydrothermal acid-sulfate system 
at Summitville, Colorado: integration of geological, stableisotope, and fluid-inclusion evidences. Chem. Geol. 215, 281315 (this volume).

Bottaro, J.L., 1987. Geology of the Middle Buttes volcanic complex, Mojave district, Kern County, California. MSc thesis, San Jose State Univ., California.

Carroll, M.R., Holloway, J.R. (Eds.), 1994. Volatiles in Magma, Rev. Mineral., vol. 30.

Carroll, M.R., Rutherford, M.J., 1988. Sulfur speciation in hydrous experimental glasses of varying oxidation state: results from measured wavelength shifts of sulfur X-rays. Am. Mineral. 73, $845-849$.

Carroll, M.R., Webster, J.D., 1994. Solubilities of sulfur, noble gases, nitrogen, chlorine, and fluorine in magmas. In: Carroll, M.R., Holloway, J.R. (Eds.), Volatiles in Magma, Rev. Mineral, vol. 30, pp. 231-279.

Chase Jr., M.W., 1998. NIST-JANAF thermochemical tables, 4th Edition. J. Phys. Chem. Ref. Data 9. 1951 p.

Craig, H., Lupton, J.E., Welham, J.A., Poreda, R., 1978. Helium isotope ratios in Yellowstone and Lassen Park volcanic gases. Geophys. Res. Lett. 5, 897.

Crerar, D.A., Barnes, H.L., 1976. Ore solution chemistry: V. Solubilities of chalcopyrite and chalcocite assemblages in hydrothermal solution at 200 to $350{ }^{\circ} \mathrm{C}$. Econ. Geol. 71, $772-794$.

Cunningham, C.G., Rye, R.O., Steven, T.A., Mehnert, H.H., 1984. Origins and exploration significance of replacement and veintype alunite deposits in the Marysvale volcanic field, west central Utah. Econ. Geol. 79, 50-71.

Cunningham, C.G., Rye, R.O., Bethke, P.M., Logan, M.A.V., 1996. Formation of coarse-grained vein alunite by degassing of an epizonal stock. Chapman Conference on Crater Lakes, Terrestrial Degassing and Hyper-Acid Fluids in the Environment. Extended Abs., Sept. 4-9, 1996, Crater Lake, OR. American Geophysical Union, Washington, DC, p. 27.

Deyell, C.L., 2002. Synchronous Au-alunite in the Pascua-Lama high sulfidation system: constraints on the origin and chemistry of mineralizing fluids. Geol. Soc. Am. Abstr. Programs 34 (6), 186.

Deyell, C.L., Rye, R.O., Landis, G.P., Bissig, T., 2005. Alunite and the role of fluids in the Tambo high-sulfidation deposit, El Indio-Pascua belt, Chile. Chem. Geol. 215, 185-218 (this volume).

Doukas, M.P., Gerlach, T.M., 1995. Sulfur dioxide scrubbing during the 1992 eruptions of Crater Peak, Mount Spurr Volcano, Alaska. In: Keith, T.E.C. (Ed.), The 1992 Eruptions of Crater Peak Vent, Mount Spurr Volcano, Alaska, U.S. Geol. Surv. Bull., vol. 2139, pp. 47-57.

Evans, B.W., Scaillet, B., 1997. The redox state of Pinatubo dacite and the ilmenite-hematite solvus. Am. Mineral. 82, 625-629.

Farley, K.A., Poreda, R.J., 1993. Mantle neon and atmospheric contamination. Earth Planet. Sci. Lett. 114, 325-339.

Fifarek, R.H., Rye, R.O., 2005. Stable-isotope geochemistry of the Pierina high-sulfidation $\mathrm{Au}-\mathrm{Ag}$ deposit, Peru: influence of hydrodynamics on $\mathrm{SO}_{4}^{2-} \mathrm{H}_{2} \mathrm{~S}$ isotopic exchange in magmaticsteam and steam-heated environments. Chem. Geol. 215, 253279 (this volume).
Fournier, R.O., 1987. Conceptual models of brine evolution in magmatic-hydrothermal systems. U.S. Geol. Surv. Prof. Pap. 1350 (2), 1487-1506.

Fournier, R.O., 1999. Hydrothermal processes related to movement of fluid from plastic into brittle rock in the magmatic-epithermal environment. Econ. Geol. 94, 1193-1211.

Gerlach, T.M., 1980. Investigation of volcanic gas analyses and magma outgassing from Erta'Ale lava lake, Afar, Ethiopia. J. Volcanol. Geotherm. Res. 7, 415-441.

Gerlach, T.E., 1986. Exsolution of $\mathrm{H}_{2} \mathrm{O}, \mathrm{CO}_{2}$, and $\mathrm{S}$ during eruptive episodes at Kilauea Volcano, Hawaii. J. Geophys. Res. 91, $12177-12185$.

Gerlach, T.E., 1993a. Thermodynamic evaluation and restoration of volcanic gas analyses: an example based on modern collection and analytical methods. Geochem. J. 27, 305-322.

Gerlach, T.E., 1993b. Oxygen buffering of Kilauea volcanic gases and the oxygen fugacity of Kilauea basalt. Geochim. Cosmochim. Acta 57, 795-814.

Gerlach, T.E., Casadevall, T.S., 1986. Evaluation of gas data from high-temperature fumaroles at Mount St. Helens, 1980-1982. J. Volcanol. Geotherm. Res. 28, 107-140.

Gerlach, T.M., McGee, K.A., 1994. Total sulfur dioxide emissions and pre-eruption vapor-saturated magma at Mount St. Helens, 1980-88. Geophys. Res. Lett. 21, 2833-2836.

Gerlach, T.M., McGee, K.A., 1998. Rates of volcanic $\mathrm{CO}_{2}$ degassing from airborne determinations of $\mathrm{SO}_{2}$ emission rates and plume $\mathrm{CO}_{2} / \mathrm{SO}_{2}$ : test study at Pu'u'O'o cone, Kilauea volcano, Hawaii. Geophys. Res. Lett. 25, 2675-2678.

Gerlach, T.E., Nordlie, B.E., 1975. The C-O-H-S gaseous system: Part II. Temperature, atomic composition, and molecular equilibria in volcanic gases. Am. J. Sci. 275, 377-394.

Gerlach, T.M., Doukas, M.P., McGee, K.A., Kessler, R., 1999. Airborne detection of diffuse carbon dioxide emissions at Mammoth Mountain, California. Geophys. Res. Lett. 26, 3661-3664.

Gerlach, T.M., McGee, K.A., Elias, T., Sutton, A.J., Doukas, M.P., 2002. Carbon dioxide emission rate of Kilauea volcano: implications for primary magma and summit reservoir. J. Geophys. Res. 107, 2189-2203.

Giggenbach, W.F., 1987. Redox processes governing the chemistry of fumarolic gas discharges from White Island, New Zealand. Appl. Geochem. 2, 143-161.

Giggenbach, W.F., 1992. Magma degassing and mineral deposition in hydrothermal systems along convergent plate boundaries. Econ. Geol. 87, 1927-1944.

Giggenbach, W.F., 1996. Chemical composition of volcanic gases. In: Scarpa, R., Tilling, R.I. (Eds.), Monitoring and Mitigation of Volcano Hazards. Springer Verlag, Berlin, pp. 221-256.

Giggenbach, W.F., 1997. The origin and evolution of fluids in magmatic-hydrothermal systems. In: Barnes, H.L. (Ed.), Geochemistry of Hydrothermal Ore Deposits, 3rd ed. Wiley, New York, pp. 737-796.

Giggenbach, W.F., Le Guern, F., 1976. The chemistry of magmatic gases from Erta'Ale, Ethiopia. Geochim. Cosmochim. Acta 40, $25-30$.

Goldfarb, R.J., Leach, D.L., Rose, S.C., Landis, G.P., 1989. Fluid inclusion geochemistry of gold-bearing quartz veins of the 
Juneau Gold Belt, southeastern Alaska-implications for ore genesis. In: Keays, R.R., Ramsay, R.H., Groves, D.I. (Eds.), The Geology of Gold Deposits: The Perspective in 1988, Econ. Geol. Monogr., vol. 6, pp. 363-375.

Graney, J.R., Kesler, S.E., 1995. Gas composition of inclusion fluid in ore deposits: is there a relation to magmas? In: Thompson, J.F.H. (Ed.), Magmas, Fluids, and Ore Deposits, Mineral. Assoc. Can. Short Course, vol. 23, pp. 221-245.

Hedenquist, J.W., 1995. The ascent of magmatic fluid: discharge versus mineralization. In: Thompson, J.F.H. (Ed.), Magmas, Fluids, and Ore Deposits, Mineral. Assoc. Can. Short Course, vol. 23 , pp. $263-289$.

Hedenquist, J.W., Lowenstern, J.B., 1994. The role of magmas in the formation of hydrothermal ore deposits. Nature 370 , $519-527$.

Hofstra, A.H., Leventhal, J.S., Northrop, H.R., Landis, G.P., Rye, R.O., Birak, D.J., Dahl, A.R., 1991. Genesis of sediment-hosted disseminated gold deposits by fluid mixing and sulfidization: chemical reaction-path modeling of ore depositional processes documented in the Jerritt Canyon district, Nevada. Geology 19, $36-40$.

Holland, H.D., 1965. Some applications of thermochemical data to problems of ore deposits: II. Mineral assemblages and the composition of ore-forming fluids. Econ. Geol. 60, 1101-1166.

Honda, M., McDougall, I., Patterson, D.B., 1993. Solar noble gases in the Earth: the systematics of helium-neon isotopes in mantle derived samples. Lithos 30, 257-265.

Huebner, J.S., Sato, M., 1970. The oxygen fugacity-temperature relationships of manganese oxide and nickel oxide buffers. Am. Mineral. 55, 934-952.

Jannas, R.R., Bowers, T.S., Petersen, U., Beane, R.E., 1999. Highsulfidation deposit types in the El Indio District, Chile. In: Skinner, B.J. (Ed.), Geology and Ore Deposits of the Central Andes, Soc. Econ. Geol. Spec. Pub., vol. 7, pp. 27-59.

Juliani, C., Rye, R.O., Nunes, C.M.D., Snee, L.W., Corréa Silva, R.H., Monteiro, L.V.S., Bettencourt, J.S., Neumann R., Neto, A.A., 2005. Paleoproterozoic high-sulfidation mineralization in the Tapajós gold province, Amazonian craton, Brazil: geology, mineralogy, alunite argon-age, and stable-isotope constraints. Chem. Geol. 215, 95-125 (this volume).

Kennedy, B.M., Hiyagon, H., Reynolds, J.H., 1990. Crustal neon: a striking uniformity. Earth Planet. Sci. Lett. 98, 277-286.

Kyser, T.K., Rison, W., 1982. Systematics of rare gas isotopes in basic lavas and ultramafic xenoliths. J. Geophys. Res. 87, $5611-5630$.

Landis, G.P., Hofstra, A.H., 1991. Fluid inclusion gas chemistry as a potential minerals exploration tool: case studies from Creede, CO, Jerritt Canyon, NV, Coeur d'Alene district, ID and MT, southern Alaska mesothermal veins, and mid-continent MVT's. J. Geochem. Explor. 42, 25-59.

Landis, G.P., Rye, R.O., 1989. Reconnaissance gas chemistry of the Creede, Colorado, hydrothermal system. U.S. Geol. Surv. OpenFile Rep. 89-0084.

Landis, G.P., Snee, L.W., Juliani, C., 2005. Evaluation of alunite argon ages and fluid-inclusion integrity: stepwise noble-gas heating experiments on $1.87 \mathrm{Ga}$ alunite from Tapajós Province, Brazil. Chem. Geol. 215, 127-153 (this volume).
Luhr, J.F., Melson, W.G., 1996. Mineral and glass compositions in June 15, 1991, pumices: evidence for dynamic disequilibrium in the dacite of Mount Pinatubo. In: Newhall, C.G., Punongbayan, R.S. (Eds.), Fire and Mud: Eruptions and Lahars of Mount Pinatubo, Philippines. PHIVOLS and Univ. Washington Press, pp. 733-749.

Manning, C.E., Ingebritsen, S.E., 1999. Permeability of the continental crust: implications of geothermal data and metamorphic systems. Rev. Geophys. 37, 127-150.

Moore, J.N., Norman, D.I., Kennedy, B.M., 2001. Fluid inclusion gas compositions from an active magmatic-hydrothermal system: a case study of The Geysers geothermal field, USA. Chem. Geol. 173, 3-30.

Muntean, J.L., Einaudi, M.T., 2001. Porphyry-epithermal transition: Maricunga belt, northern Chile. Econ. Geol. 96, 743-772.

Norman, D.I., Musgrave, J.A., 1994. $\mathrm{N}_{2}-\mathrm{Ar}-\mathrm{He}$ compositions in fluid inclusions: indicators of fluid source. Geochim. Cosmochim. Acta 58, 1119-1131.

Ohmoto, H., 1986. Stable isotope geochemistry of ore deposits. In: Valley, J.E., Taylor Jr., H.P., O’Neil, J.R. (Eds.), High Temperature Geological Processes, Rev. Mineral., vol. 16, pp. $491-560$.

Ohmoto, H., Rye, R.O., 1979. Isotopes of sulfur and carbon. In: Barnes, H.L. (Ed.), Geochemistry of Hydrothermal Ore Deposits, 2nd ed. Wiley, New York, pp. 509-567.

O'Neill, H.St.C., 1987. Quartz-fayalite-iron and quartz-fayalitemagnetite equilibria and the free energy of formation of fayalite $\left(\mathrm{Fe}_{2} \mathrm{SiO}_{4}\right)$ and magnetite $\left(\mathrm{Fe}_{3} \mathrm{O}_{4}\right)$. Am. Mineral. 72, 67-75.

O'Nions, R.K., Ballentine, C.J., 1993. Rare gas studies of basin scale fluid movement. Philos. Trans. R. Soc. London 344, $141-156$.

Ozima, M., Igarashi, G., 2000. The primordial noble gases in the earth: a key constraint on Earth evolution models. Earth Planet. Sci. Lett. 176, 219-232.

Ozima, M., Podosek, F.A., 2002. Noble Gas Geochemistry. 2nd ed. Cambridge Univ. Press, New York.

Plumlee, G.S., Leach, D.L., Hofstra, A.H., Landis, G.P., Rowan, E.L., Viets, J.G., 1994. Chemical reaction path modeling of ore deposition in Mississippi Valley-type $\mathrm{Pb}-\mathrm{Zn}$ deposits of the Ozark region, U.S. midcontinent. Econ. Geol. 89, 1361-1383.

Roedder, E., 1984. Fluid inclusions. Rev. Mineral. 12, 644 p.

Rose, W.I., Chuan, R.L., Giggenbach, W.F., Kyle, P.R., Symonds, R.B., 1986. Rates of sulfur dioxide and particle emissions from White Island volcano, New Zealand, and an estimate of the total flux of major gaseous species. Bull. Volcanol. 48, $181-188$.

Rowley, P.D., Mehnert, H.D., Naeser, C.W., Snee, L.W., Cunningham, C.G., Steven, T.A., Anderson, J.J., Sable, E.G., Anderson, R.E., 1994. Isotopic ages and stratigraphy of Cenozoic rocks of the Marysvale volcanic field and adjacent areas, west-central Utah. U.S. Geol. Surv. Bull. 2071, 35 p.

Rye, R.O., 1993. The evolution of magmatic fluids in the epithermal environment: the stable isotope perspective. Econ. Geol. 88, $733-753$.

Rye, R.O., 2005. A review of the stable-isotope geochemistry of sulfate minerals in selected igneous environments and related hydrothermal systems. Chem. Geol. 215, 5-36 (this volume). 
Rye, R.O., Bethke, P.M., Wasserman, M.D., 1992. The stable isotope geochemistry of acid sulfate alteration. Econ. Geol. 87, $225-262$.

Sarda, P., Staudacher, T.J., Allégre, C.J., 1988. Neon isotopes in submarine basalts. Earth Planet. Sci. Lett. 91, 73-88.

Sato, M., 1978. Oxygen fugacity of basaltic magmas and the role of gas-forming elements. Geophys. Res. Lett. 5, 447-449.

Sato, M., Wright, T.L., 1966. Oxygen fugacities directly measured in magmatic gases. Science 153, 1103-1105.

Shibata, T., Takahashi, E., Matsuda, J., 1998. Solubility of neon, argon, krypton, and xenon in binary and ternary silicate systems: a new view on noble gas solubility. Geochim. Cosmochim. Acta $62,1241-1253$.

Smith, A., 1941. The geochemistry and paragenesis of the ores of the Cactus mine, Kern County, California. PhD thesis, California Inst. Technol., Pasadena.

Smith, R.B., Bruhn, R.L., 1984. Interplate extensional tectonics of the eastern Basin-Range: inferences on structural style from seismic reflection data, regional tectonics, and thermal mechanical models of brittle-ductile deformation. J. Geophys. Res. 89, $5733-5762$.

Snyder, G., Poreda, R., Hunt, A., Fehn, U., 2001. Regional variations in volatile composition: isotopic evidence for carbonate recycling in the Central American volcanic arc. Geochem. Geophys. Geosyst. $\left(\mathrm{G}^{3}\right)$ 2, 1-25. (2001GC000163).

Stoffregen, R., 1987. Genesis of acid-sulfate alteration and $\mathrm{Au}-\mathrm{Cu}-$ Ag mineralization at Summitville, Colorado. Econ. Geol. 82, $1575-1591$.

Stoffregen, R.E., Alpers, C.N., Jambor, J.L., 2000. Alunite-jarosite crystallography, thermodynamics, and geochronology. In: Alpers, C.N., Jambor, J.L., Nordstrom, D.K. (Eds.), Sulfate Minerals - Crystallography, Geochemistry, and Environmental Significance, Rev. Mineral. Geochem., vol. 40, pp. $453-479$.
Symonds, R.B., Reed, M.H., 1993. Calculation of multicomponent equilibria in gaseous-solid-liquid systems: calculation methods, thermochemical data, and applications to studies of hightemperature volcanic gases with examples from Mt. St. Helens. Am. J. Sci. 293, 758-864.

Symonds, R.B., Rose, W.I., Gerlach, T.M., Briggs, P.H., Harmon, R.S., 1990. Evaluation of gases, condensates, and $\mathrm{SO}_{2}$ emissions from Augustine volcano, Alaska: the degassing of a Cl-rich volcanic system. Bull. Volcanol. 52, 355-374.

Symonds, R.B., Reed, M.H., Rose, W.I., 1992. Origin, speciation, and fluxes of trace-element gases at Augustine volcano, Alaska: insights into magma degassing and fumarolic processes. Geochim. Consmochim. Acta 56, 633-657.

Symonds, R.B., Rose, W.I., Bluth, G.J.S., Gerlach, T.M., 1994. Volcanic-gas studies: methods, results, and applications. In: Carroll, M.R., Holloway, J.R. (Eds.), Volatiles in Magmas, Rev. Mineral., vol. 30, pp. 1-66.

Symonds, R.B., Gerlach, T.M., Reed, M.H., 2001. Magmatic gas scrubbing: implications for volcano monitoring. J. Volcanol. Geotherm. Res. 108, 303-341.

Troxel, B.W., Morton, P.K., 1962. Mines and mineral resources of Kern County, California. Calif. Div. Mines Geol. County Rept. $1,370 \mathrm{p}$.

Weiss, R.F., 1970. The solubility of nitrogen, oxygen, and argon in water and seawater. Deep-Sea Res. 17, 721-735.

Weiss, R.F., 1971. Solubility of helium and neon in water and seawater. J. Chem. Eng. Data 16, 235-241.

Yatsevich, I., Honda, A., 1997. Production of nucleogenic neon in the Earth from natural radioactive decay. J. Geophys. Res. (Solid Earth) 102 (B5), 10291-10298.

Zimbelman, D.R., Rye, R.O., Landis, G.P., 2000. Fumaroles in ice caves on the summit of Mount Rainier-preliminary stable isotope, gas, and chemical studies. J. Volcanol. Geotherm. Res. $97,457-473$. 